\title{
Green Walls, a Critical Review: Knowledge Gaps, Design Parameters, Thermal Performances and Multi-Criteria Design Approaches
}

\author{
Fabrizio Ascione ${ }^{1, *(\mathbb{D})}$, Rosa Francesca De Masi ${ }^{2}$, Margherita Mastellone ${ }^{1}$, Silvia Ruggiero ${ }^{2}$ and \\ Giuseppe Peter Vanoli ${ }^{3}$ \\ 1 Department of Industrial Engineering, Università degli Studi di Napoli Federico II, Piazzale Tecchio, 80, \\ 80125 Napoli, Italy; margherita.mastellone@unina.it \\ 2 Department of Engineering, Università degli Studi del Sannio, Piazza Roma, 21, 82100 Benevento, Italy; \\ rfdemasi@unisannio.it (R.F.D.M.); sruggiero@unisannio.it (S.R.) \\ 3 Department of Medicine and Health Sciences "Vincenzo Tiberio", Università degli Studi del Molise, \\ Via Francesco De Sanctis, 86100 Campobasso, Italy; giuseppe.vanoli@unimol.it \\ * Correspondence: fabrizio.ascione@unina.it; Tel.: +39-081-7682292
}

Received: 22 March 2020; Accepted: 14 April 2020; Published: 1 May 2020

\begin{abstract}
The green wall is an engineered technology for stormwater management and climate change mitigation at the urban level. At the building scale, these energy efficiency measures are suitable for improving indoor comfort conditions and for reducing energy needs. Several guidelines are available about vertical greening systems, but these propose design parameters and performance evaluation criteria, often incomparable. In order to facilitate the implementation of proper technical standards, this paper proposes a critical review of more recent scientific investigations. All parameters for the design optimization are discussed as well as the achievable social and private benefits by taking into consideration the type of study (numerical or experimental), the climate conditions, the analysis period, all technical requirements of the green layer as well as of the back wall. The review underlines that a multi-criteria design approach is needed for green vertical systems. Thus, the paper is concluded with a SWOT analysis, evidencing "strengths", "weaknesses", "opportunities" and "threats". The analysis shows that the highlighted benefits will acquire greater relevance considering the increase in global temperatures and the growing need to redevelop densely built urban centers, while some negative aspects may be filled in the future with a deeper preparation of designers and careful choice of materials. The review paper shows, therefore, drivers and barriers occurring designing and implementing green walls.
\end{abstract}

Keywords: green walls; thermal behavior; urban quality; building performance; sustainability; building simulation; energy retrofit

\section{Table of Contents}

1. Introduction

1.1 Motivation for a New Critical Literature State of the Art ... . . . . . . . . . . . . . 2

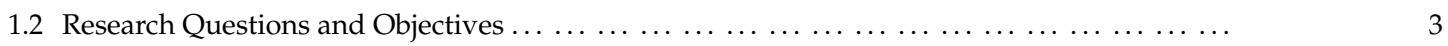

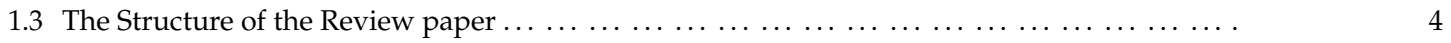

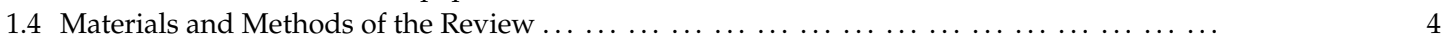

2. Vertical Greening Systems Performance Evaluation $\quad 5$

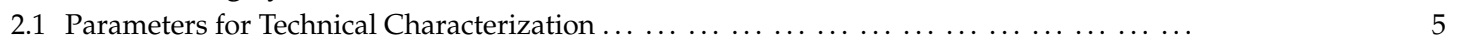

2.2 Mathematical Models for the Greening Systems' Performance Evaluation $\quad 15$

3. A Critical Overview of Vertical Greening Systems' Performances 17

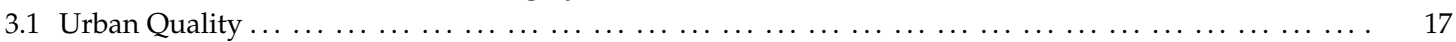




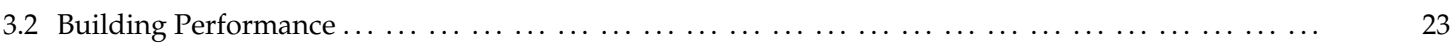

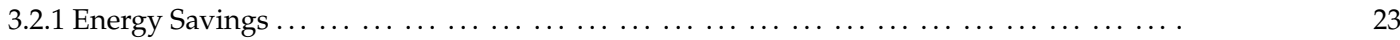

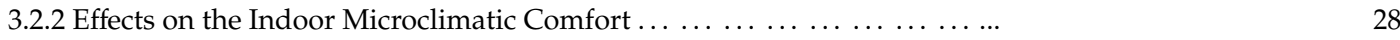

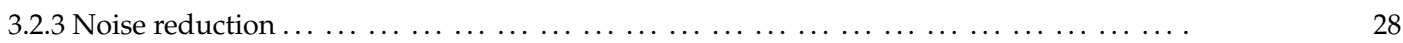

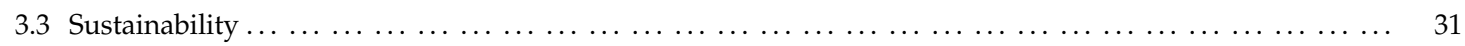

4. Remarks from the Review Process $\quad 33$

$\begin{array}{lr}\text { 5. Conclusions } & 37\end{array}$

$\begin{array}{ll}\text { References } & 38\end{array}$

\section{Introduction}

\subsection{Motivation for a New Critical Literature State of the Art}

One of the 17 objectives of the Agenda for Sustainable Development forward 2030 is to make cities and human settlements inclusive, safe, resilient and sustainable. Among the most environmentally friendly solutions, the green wall $(G W)$ can be utilized as a key strategy for cleaning air and water, for climate change mitigation and adaptation and for promoting the local biodiversity and character [1]. $G W$ is the most common term used to refer to all forms of a technological system consisting of vertical building elements covered with plants, including all elements for supporting their growth. The most common classification [2-4] distinguishes between: a) Green Façades (GFs) and b) Living Wall (LWs).

The green façades are made of climbing plants growing on a wall without additional infrastructures (direct system), or with the use of stainless steel or wooden trellis, meshwork, or cabling as a support (indirect system). A GW can be created both with plants grown in garden beds at its base or with containers installed at different levels across the building. Some Asian examples are reported in Figure 1, while other European examples are shown in Figure 2.

\section{CITY OF SINGAPORE: THREE EXEMPLES}

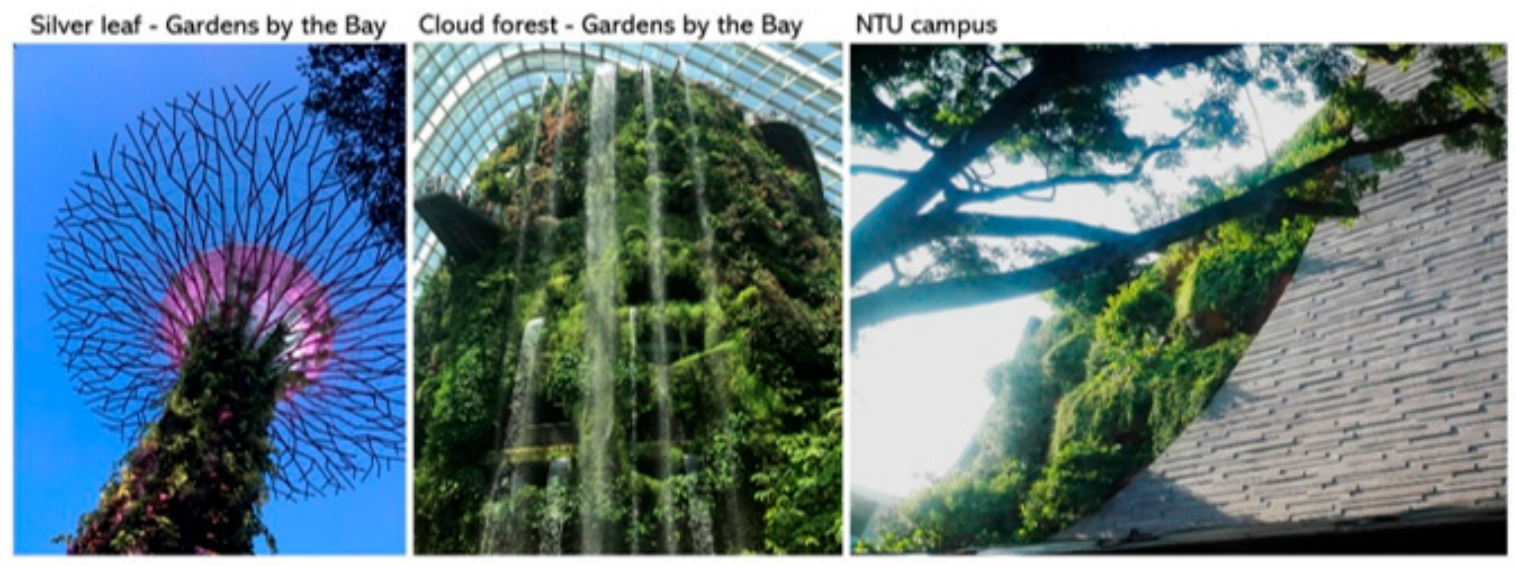

Figure 1. Three examples of green walls in the City of Singapore.
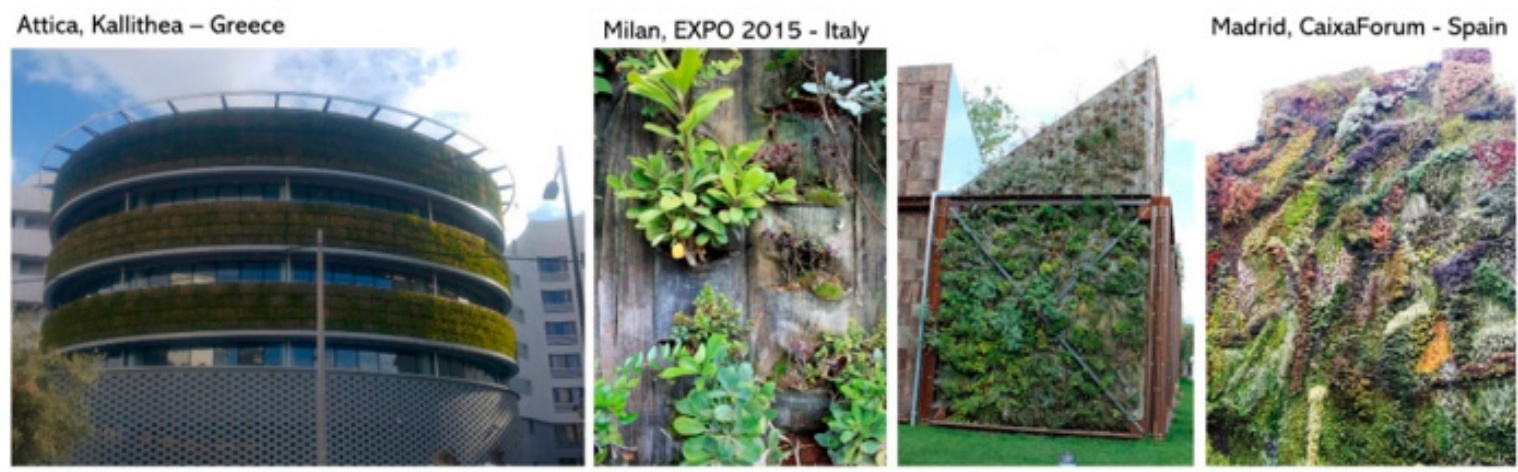

Figure 2. Examples of green walls in Europe. 
LWs are characterized by vegetation that is not connected to the façade but rather it is fully integrated with the building envelope. Plants and substrate are both placed on the vertical surface of the external wall, typically on the external side of an impermeable and anti-root membrane, in order to protect the structure from moisture, with or without an air gap. Continuous and modular systems $[2,4]$ are both possible technologies. Some admirable architectures, for both public and private uses, have become iconic due to the perfect integration between the vegetation and the architectural project, for example: the "Caixa Forum" of Herzog \& de Meuron in Madrid, the "Solaris" office building of Ken Yeang in Singapore, the "University Pole of Management Sciences" of Lacaton\&Vassal in Bordeaux, the "Hardman Square Pavilion" of Sheppard Robson in Manchester or the "Vertical Forest" of Stefano Boeri in Milan.

These systems can reduce the energy demand of buildings both in summer and winter mainly by means of the following mechanisms:

- the shading produced by the vegetation;

- the evaporative cooling achieved by evapotranspiration from the plants and from the crop substrate;

- the insulation provided by vegetation and substrate as well as the variation of the wind effect [5].

Despite the advantages, the adoption of green systems has a penetration into the construction market still too low. The main criticalities [6] seem to consist in: (a) high investment and maintenance costs, (b) lack of a shared constructive standard, (c) hard interpretation of not uniform experimental data and (d) unavailability of certified commercial simulation models.

Some review studies on green vertical systems are already available, and these are mainly focused on:

- classification [2] of typologies;

- $\quad$ state of the art of technologies [7,8];

- evaluation of the thermal performance $[9,10]$ or of the human health benefits [11];

- estimation of effects on thermal comfort and carbon emission reduction [12].

Reasons and motivations for a new review study are:

* the aim of a deep focus on the discussion of designing and performance evaluation methodology;

* deepening of aspects related to numerical simulations, with clear indication on data concerning the parameters for characterization;

* the research of univocal and clear data interpretation in term of benefits and problems;

* a new comparison among the same GW in different climates.

\subsection{Research Questions and Objectives}

This review is aimed at proposing a critical analysis of available results with experimental or numerical approach, in terms of designing methodology and environmental benefits, with the scope to orientate the future research and to help designers. The main topics discussed are:

(a) Given the correlation between vegetation characteristics and the effective performance, how many parameters are needed for describing the energy behavior of a GW? Could these parameters be considered constant over time? How they can be measured? Are they available for different type of plants? General description will be translated to concrete technical data as leaf area index $(L A I)$, height, substrate type, irrigation type and schedule;

(b) Which are the advantages and disadvantages of green vertical systems? Experimental and numerical data are compared according to the climate (location), the system composition, the considered period, the indoor conditions;

(c) Can the scientific results be translated into shared building standards and methods for the optimal design? 


\subsection{The Structure of the Review Paper}

This paper is organized in three sections: after the Introduction (Section 1), Section 2 discusses the accuracy of available experimental data and the reliability of adopted simulation models for characterizing the GWs' performance. Moreover, Section 3 presents a critical analysis of available results taking into account the effects on urban rehabilitation, building performance improvement, sustainability and profitability during the lifecycle. Then, a discussion is proposed (Section 4). Finally, the paper ends with a SWOT matrix that allows visualizing the different internal strengths and weaknesses of a building solution and its external opportunities, threats and weaknesses that might be faced during project management.

\subsection{Materials and Methods of the Review}

In order to review the scientific literature, the publications on different topic combinations stored in the Web of Science (www.isiwebofknowledge.com) database were analyzed, until March 2020. A protocol for providing a revision of GWs does not exist. In our study, we have collected papers, of the past and recent literature (latest 20 years), according to experimental and numerical criteria, by taking into about 100 studies.

The selection of the reviewed studies has been organized according to a two-step methodology: in a first step, papers about the $G W$ systems and its characteristics were reviewed, in a second step, the ones based on the environmental effects of a GW system have been summarized. More in detail:

- $\quad$ around 45 scientific studies were reviewed on the topics of "green wall" + "sub-system" + "plant system," in order to evaluate the availability of technical data.

- around 55 scientific studies were review on the topics of "green wall" + "energy and/or environmental performance" with which vantages and disadvantages of this technology have been found.

Figure 3 shows a diagram of the literature research approach. The search strategy in the Web of Science Database was performed by defining keywords such as green walls, living walls, green facades, green systems but also the more generic ones such as bioclimatic solutions or wall systems. In some cases, the papers' research was carried out by selecting the name of authors already known for published papers about GFs such as Perini, Prodanovic, Olivieri, Pérez, and Djedjig. Of course, some limits were applied to circumscribe the search results: only articles published after 2000, in the English language, in international journals and authoritative conference proceedings.

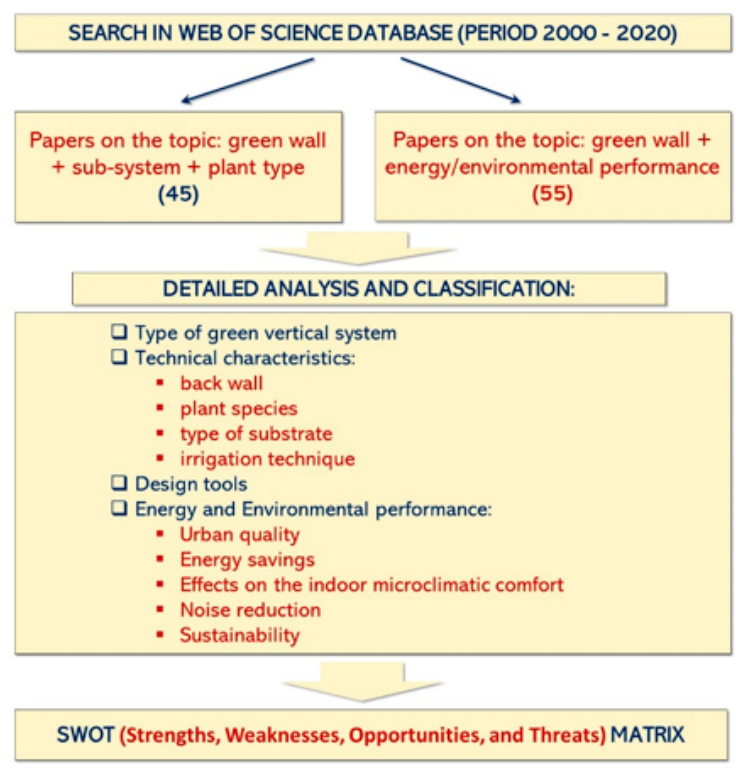

Figure 3. PRISMA flow diagram: the review method. 
Please, note that the citation of each paper can be singular or twice or it can happen even more times. Indeed, according to the various sections of this review, and thus the investigation of GWs according to several points of view (thermal and energy performance, thermal comfort, environmental noise reduction, sustainability, etc.), each paper can be cited more than one time. The data extracted, are referred to different climates, different approaches and different observation periods, so that often, some divergences occur, and not unique trends are always achieved.

\section{Vertical Greening Systems Performance Evaluation}

This review proposes to split out the problem of performance evaluation in two categories, by taking into account the availability of:

(a) accurate description parameters or their measurements for experimental studies;

(b) numerical model for parametric studies or predictive evaluations.

\subsection{Parameters for Technical Characterization}

Some examples of green walls are proposed in [13], in which the authors show some typologies of hanging greenery as a solution for improving the Environmental Sustainability of buildings. The parameters needed for studying the behavior of vertical green systems can be obtained by the analysis of involved heat transfer phenomena:

$\checkmark \quad$ long and short-wave radiative heat transfer within the vegetation canopy;

$\checkmark \quad$ long and short-wave radiative exchange within the wall not covered by plants or the soil not covered by the plants;

$\checkmark \quad$ plant-wall or plant-soil radiative heat transfer;

$\checkmark \quad$ plant canopy effects on convective heat transfer;

$\checkmark \quad$ transpiration from plants, and evaporative effect from soil;

$\checkmark$ heat conduction from and to the back wall and soil layer;

$\checkmark \quad$ the role played by the wall and soil thermal inertia.

Some necessary definitions should be provided immediately. First of all, the Leaf Area Index (LAI) quantifies the fractional vegetation coverage; it is the "total one-sided projected leaf area" to "the ground surface area" ratio [14]. For instance, a LAI equal to 3 indicates that there are $3 \mathrm{~m}^{2}$ of projected leaf per $1 \mathrm{~m}^{2}$ of below (or behind) surface. $L A I$ sometimes is dimensionless, sometimes is reported with the unit: i.e., $\mathrm{m}^{2}$ (foliage) $/ \mathrm{m}^{2}$ (soil). The main measurement methods for the determination of $L A I[15]$ are:

- DIRECT: harvesting the vegetation and measuring the area of all the leaves within a delimited area;

- SEMI-DIRECT: collecting leaves of deciduous plants, drying and weighing them and after converting the mass into leaf area by multiplying the collected biomass by the Specific Leaf Area (SLA);

- INDIRECT: measuring the transmission of radiation through the canopy, by using the radiative transfer theory.

The first one is an accurate but a destructive method; it is really suitable for vegetation of small structure. An example of application is reported by Charoenkit and Yiemwattana [16]. The second one is non-destructive, but the estimation of SLA is difficult due to its variation with species, site fertility, date and year, duration of remaining in the traps, weather. Conversely, non-destructive indirect methods need calibration procedure. It has been verified that the indirect methods underestimate (from $25 \%$ to $50 \%$ ) the $L A I$ compared with direct measurement. Several indirect methods have experimented.

Koyama et al. [17] have used digital pictures taken each week. It is an easily implemented method and non-invasive, but it does not give the information about the stratification of leaves and thus the real LAI. Pérez et al. [18] have compared a direct method based on delta-T image analysis system and 
an indirect method based on the estimation of $L A I$, using the amount of light energy transmitted by a plant canopy. In this case, the values are convergent: for the proposed case study, $L A I$ is 3.1 with the direct method and 3.3 with the indirect method of measure. Conversely, for the same type of plants, Susorova et al. [19] have found $L A I=1.8$, by measuring the area of a typical leaf and counting the area of ivy leaves in an image of the vegetal wall. It can be concluded that it is very difficult to obtain a representative $L A I$ for the same plant species.

In order to evaluate peculiarities and performances of GWs, another important parameter is the radiation attenuation coefficient $(k)$ that indicates the decrease in the absorbed radiation of the leaves; for instance, this parameter is 0 if leaves are perpendicular to the wall.

The evaluation of short wave radiative exchanges needs of absorption coefficient $\left(\alpha_{l}\right)$ and also of transmission coefficient through the plant layer. For the long wave radiation exchange, the emissivity of the leaf $\left(\varepsilon_{l}\right)$ is also necessary. The same parameters are also needed for the soil (in the following $\alpha_{s}$ is absorption coefficient and $\varepsilon_{s}$ is emissivity) and for the back wall not covered by the vegetation. Moreover, it should be noted that, as known, spectral parameters can vary if soil and/or wall are wet or dry.

Since it affects the wind velocity on the wall surface, the height of the plants plays an important role in convective heat transfer and evapotranspiration. The transpiration of the plants is a natural physiological process during which the water taken from the soil by roots, passes through the plant and then is evaporated from cells (called stomata) in the leaf. It is described by leaf stomatal conductance (or conversely the stomatal resistance, $r_{l}$ ). Transpiration is the rate of water vapor that leaves through the pores on the leaf. It depends on the number of stomatal pores per leaf surface area and the pore size [19]. In addition, evaporation from the soil depends on the maximum volumetric moisture content of the soil layer (saturation), the minimum (residual) volumetric moisture content of the soil layer and the initial volumetric moisture content of the soil layer. However, the effectiveness of evapotranspiration is strongly influenced by climatic conditions in which the plants live and are subjected and by the status and suitability of their growth. According to [20], the direct measurement of evapotranspiration could be made by using soil evaporimeters and lysimeters. These tools and techniques are categorized according to their method of operation:

(a) Weight based, which use mechanical scales to account for changes in water content.

(b) Hydraulic based, which use the hydrostatic principle of weighing.

(c) Volumetric based, in which water content is kept constant and evapotranspiration is measured by the amount of water added or removed.

Moreover, the transpiration of the plants could be obtained as difference between measured evapotranspiration and measured evaporation. Direct methods for measuring the evaporation are evaporation pans and lysimeters; indirect methods are the water-budget, the energy-budget, the aerodynamic approach or combination of these.

For the heat conduction and heat storage in the back wall and in the soil layer, thermal conductivity $(\lambda)$, density $(\rho)$, specific heat $\left(c_{p}\right)$ and thickness of each material have to be considered. Once again, for the substrate, these values could vary with the water content. Few studies present the experimentally measured values. For instance, the study [21] proposes the in-lab evaluation of thermal conductivity of each element; more in detail, they have found conductivities of $0.062 \mathrm{~W} / \mathrm{m} \mathrm{K}$ for sphagnum moss, $0.060 \mathrm{~W} / \mathrm{m} \mathrm{K}$ for outdoor planting mix, and $0.105 \mathrm{~W} / \mathrm{m} \mathrm{K}$ for clay balls and $0.051 \mathrm{~W} / \mathrm{m} \mathrm{K}$ for the substrate from a green-wall, $0.220 \mathrm{~W} / \mathrm{m} \mathrm{K}$ for Hedera and $0.274 \mathrm{~W} / \mathrm{m} \mathrm{K}$ for Virginia creeper. He et al. [22], with reference to an indirect $L W$ system in Shanghai, have indicated measured value: in detail, Vinca major Varegata plant is adopted $\left(\alpha_{l} \approx 0.70\right.$ and $\left.e_{l} \approx 0.95\right)$ with a substrate $(6 \mathrm{~cm}$, $c_{p} \approx 600 \mathrm{~kJ} / \mathrm{K}, \alpha_{s} \approx 0.8$ and $e_{s} \approx 0.9$ ) made of peat soil, powdered perlite, vermiculite aggregate and organic fertilizer; for the soil conductivity, the authors indicated this as a function of temperature, and thus $\lambda=0.374^{*}(\mathrm{~T})^{0.403} \mathrm{~W} / \mathrm{m} \mathrm{K}$. In that paper, they have estimated a LAI of 4 and the height of plant equal to $15 \mathrm{~cm}$. 
Table 1 collects all information concerning the technical data for designing a $G W$, by taking into account all sub-systems. For each paper, it has been evidenced the type of green vertical system (GST), the main materials of the back wall ( $U$ is thermal transmittance) and the presence of air gap, the plant species, their height and the $L A I$, the type of substrate and the irrigation technique. The table cannot be found elsewhere, and it is useful for providing information to the decision-maker about which plant, substrate and irrigation system could be used, by taking into consideration the climate zone and the GW type.

Moreover, if more than one plant is analyzed in the same study, the thermal behavior of them (and so the best one) can be deduced from tables presented in the following sections. Indeed, for each one of the selected papers, energy and environmental behaviors are deeply discussed.

The analysis of Table 1 allows one to see that the description of all technical sub-systems of a GW is usually not detailed and all parameters needed for the solution of heat and moisture balances are not specified. There are not studies where the stomatal resistance is calculated, while this parameter is available for green roofs; moreover, volumetric moisture content is often not declared. Only the $L A I$ and height of plant are frequently indicated. The most common value for plant height is $10 \mathrm{~cm}$. When it is specified, the air gap is usually open, for indirect $L W s$, but the thickness is greatly variable. There are not comparable configurations for the selection of vegetation species, the only recurring type is the Parthenocissus tricuspidata for the GFs.

Some information can be found from the European map, created starting from the Plant Hardiness Zone Map, published in 2012 by the Department of Agriculture of the United States; this is the standard used by gardeners and growers for determining which plants are most likely to thrive at given location. More in detail, the green façades need climbing plants. To assure the growth of these species, the main parameters that have to be taken into account are temperature and humidity. Basing on tolerance to the minimum temperatures and on the length of the winter period, the climbing plants are divided into:

- hardy species: these can live also with very low temperatures and in presence of frost (Clematis montana, Fallopia baldschuanica and Schizophragma hydrangeoides);

- half-hardy species: these can resist only occasionally at frost and must be protected during cold winter (Akebia quinata, Bouganvillea glabra, Plumbago auriculata, Trachelospermum jasminoides and Doxantha unguiscati).

Some general conclusions can be also found from a critical review. First of all, the plants adaptable in hot-dry conditions are: Smilax aspera, Clematis flammula, Eriocereus bonplandii, Tecomaria capensis and Delairea odorata. Coversely, Hedera helix and Jasminum officinale can be adapted in each climate [23]; in this case, therefore, the main aspect for the selection is the attachment mechanism [24]. Climbing plants that find a suitable support have greater performance and fitness. Plants with secretory adhesive pads (Parthenocissus tricuspida) can cling to a building wall, whereas ones with tendrils (Clematis virginiana) can cling only to narrow stems or trellises [25]. For the direct green façades, the most suitable climbing plants are the root-climbers or leaf-climbers ones, with clinging roots or adhesive pads, as Hedera helix (common ivy), Parthenocissus tricuspidata (Boston ivy) or Wisteria (Virginia creeper).

Moreover, for indirect green façades, climbers as tendril-bearers, hook-climbers or twining plants are necessary: for example, Camellia, Ceanothus, Chaenomeles, Coronilla valentine, Garrya, Fuchsia, Magnolia grandiflora and Pyracantha [23].

Furthermore, for continuous $L W s$, the most suitable species come from Gramineae group, which can be divided into six subfamilies for a total of about 7500 species [26]. The turf species are generally suitable for trampling, and they have an excellent ability to recovery from stress phenomenon. These are divided into two groups: micro-thermal and macro-thermal. The macro-thermal species requires an air temperature of about $27-35{ }^{\circ} \mathrm{C}$ [27]. They also slow their growth rate with temperatures below $20^{\circ} \mathrm{C}$ to stop completely below $10^{\circ} \mathrm{C}$. They are native species of tropical, sub-tropical and temperate areas. The macro-thermal are characterized by a deep and extensive root system, while the leaf width and their density are variable parameters, both between the species and the cultivars (cultivated or a 
man-made variety of a plant species). The macro-thermal belong to two subfamilies: the Eragrostideae family that includes Cynodon, Zoysia and Buchloe [23], and the Panicoideae group that contains Paspalum, Stenotaphrum, Pennisetum, Axonopus and Eremochloa. The micro-thermal species grow in climates with temperatures ranging from $15^{\circ} \mathrm{C}$ to $24^{\circ} \mathrm{C}$ and these do not tolerate summer stress like high ambient temperatures and lack of water. On the other hand, they can face the coldness and they can preserve their color during the winter months. All told, these are suitable for vertical surfaces not exposed excessively to the sun. The micro-thermal species come from Asia and Europe, but nowadays these are spread almost everywhere in the world [28]. Some important genera are Festuca, Poa, Lolium and Agrostis.

For modular $L W s$, herbaceous perennials should be used, since these require less maintenance and nutrients compared to turfgrass. Some plants used for modular $L W \mathrm{~s}$ in different parts of the world are:

- Sedum generis (Ajuga, Hedera Helix, Liriope, Sedum acre, Sedum album, Sedum Reflexum, Sedum sarmentosus, Sedum Sexangulare, Sedum spurium, Sedum caeruleum, Sedum pulchellum, Sedum roseum);

- Rosids class (Cotoneaster salicifolius, Cotonesater dammeri, Hypericus calycinum, Aubretia Deltoides); Magnoliophyta class (Berberis, Crategus, Pernettya, Cistus, Rosmarinum officinalis, Alyssum saxatile).

Whittinghill et al. have shown [29] that greenery systems with woody plants, including shrubs and herbaceous perennials, have higher carbon content than the turfgrass and the sedum. So the selection of these plants is more suitable. According to Charoenkit and Yiemwattana [12], in order to optimize not only the carbon storage, but also the thermal performance in hot and humid climates, plants with dense foliage, small leaf and woody branches should be chosen, like Cuphea hyssopifola H.B.K.

For what concerns the substrate and its correlation with plant species, scarce information can be found in the literature. Some of the main characteristics of the substrates are the well-draining behavior and the proper organic content (chemical, physical and microbial). The growing media can be made by organic materials such as coconut coir, peat, tree bark, or inorganic materials such as expanded clay pebbles, gravel, perlite, mineral soil, mineral wool, sand, vermiculite. Different materials are often combined; in this case, the organic component usually is less than $10 \%$ of the mix, providing, on the other hand, important nutrients to the plants [30]. The containers for plants and growing medium have to be breathable, or made with holes, because these have to favor the free outflow of excessive water. These have to be enough large to allow the spreading of the roots, but not too big, to prevent the phenomenon of suffocation and rotting due to high humidity. More in general, the space for the roots has to be proportional to the total transpiration surface of the plant, which depends on the quantity and type of its foliage. Another important aspect for the designers is the "amount of soil" to "the pot capacity" ratio. Indeed, if this ratio is high, it means much evapotranspiration and so much more frequent need of watering; on the other hand, a low value of this ratio determines greater water retention and so less frequent watering.

As regards the back wall, the direct green façades require systems that have not holes and cracks in order to avoid any possible infiltration of the climbing plants that can damage the structure. For the indirect system, one of the main issues concerns the non-self-standing species that require a support system. Considering the LWs, a critical aspect is the waterproofing of the envelope. The adoption of an air gap between the back structure and the $L W$ is a possible solution to limit this problem. Chen et al. [31] have carried out an experimental campaign in hot and humid climates, showing that a $L W$ with a sealed air layer performs better compared to a naturally ventilated air layer, in terms of cooling effect, but the back wall is subjected to higher humidity. The insulation level of back wall is usually not indicated and thus it is not possible to discuss the effect of green system on thermal resistance; it could be interesting an optimization of the back wall composition in function of GW type, plant species and climatic conditions. The numerical study of Kontoleon and Eumorfopoulou [32] only indicates that for a direct $G W$ located in a humid subtropical climate zone, the cooling load is lower if the insulation is located in the middle or in the inner sides.

The design of the irrigation system is not discussed in the available literature. According to our opinion, it is important for the survival of plants and it implies an additional electric consumption, 
due mainly to pumps. This cost has to be taken into account in the annual energy balance of the building, in order to evaluate the economic and energetic profitability of a green system. The pumps could be scheduled or, even more appropriate, these could be automatically activated by a humidity sensor placed in the root area. The historical trend of rainfall on the site has to be compared with the rate of water that the plants need in order to understand and clearly identify the contribution of the direct irrigation. This is the precaution to overcome the unsustainable use of water for irrigation [7]. There are some strategies to decrease the consumption of water. For instance, Manso and Castro-Gomes [33] have installed, on the same wall, plants that require less watering on the top (like Sedum species), and plants that need more water on the bottom part (like Thymus species). In this way, it is possible to take advantage by the vertical displacement of irrigation water by gravity. Another possibility, as explained in Mårtensson et al. [34], is the selection of materials for the substrate with high water holding capacity (i.e., rockwool panel) that could be irrigated with larger volumes at sparser intervals, without risk of increasing runoff.

As regards the sizing of the spaces, the information to be taken into account are:

- the pipes' diameter (which depends on the rate, the speed and the pressure of water);

- the pumps;

- the sensors;

- the drip tray placed at the bottom for collecting the water excess runoff from the system.

It must be also emphasized that the irrigation system needs ordinary and extra-ordinary maintenance, with the aim of checking for water leaks, clearing debris from irrigation injectors, inspecting any controllers and sensors, replacing electronic devices if needed, verifying the proper water flow and pressure [30].

About the climatic conditions, the knowledge and also the evaluation of air temperature and surface temperature are not enough for studying the $G W$ thermal behavior. These could be considered the most representative parameters but, in the same way, these are not exhaustive of all benefits that a GW can bring. Susorova et al. [19], by means a sensitivity analysis, have shown that the most effective weather parameters, in order of their importance, are solar radiation, wind speed, relative humidity, and outdoor air temperature.

Hunter et al. [10] have suggested six parameters that all experimental studies about green façade should report, in order to have an adequate quantification of thermal performance and microclimatic benefit:

$\checkmark$ solar radiation in front of or away from the green façade;

$\checkmark \quad$ air temperature in front of or away from the green façade;

$\checkmark \quad$ wind speed in front of or away from the green façade;

$\checkmark$ solar radiation between green façade and the wall;

$\checkmark \quad$ air temperature between green façade and the wall;

$\checkmark \quad$ wind speed between the green façade and the wall.

According to authors, for accurate characterization of the green façade, also the infrared radiation emitted and intercepted by the green canopy and the relative humidity in front of and away from the green façade could be interesting in order to better understand the contribution of such systems for what concerns the reduction of heat islands and the improvement of hygro-thermal conditions. Moreover, considering the $L W$ systems, according to us, surface temperature and the inside temperature of the substrate can provide other important information concerning the usefulness and the thermal performances. 
Table 1. Data available in scientific literature for GWs (please, note that GF is Green Façade, $L W$ is Living Wall and N stands for configuration).

\begin{tabular}{|c|c|c|c|c|c|c|c|c|}
\hline Ref. & GST & Air Gap & Back Wall (in to out) & Plant Species & $L A I\left[\mathrm{~m}^{2} / \mathrm{m}^{2}\right]$ & Height $[\mathrm{cm}]$ & Substrate Type & $\begin{array}{c}\text { Irrigation Type } \\
\text { and Schedule }\end{array}$ \\
\hline [16] & Indirect $L W$ & $0.05 \mathrm{~cm}$ & Fibercement & $\begin{array}{l}\text { 1. Cuphea hyssopifola, } \\
\text { 2. Tibouchina urvilleana, } \\
\text { 3. Excoecaria cochinchinensis }\end{array}$ & $\begin{array}{lr}1 . & 5.06 \\
2 . & 3.69 \\
\text { 3. } & 3.85\end{array}$ & & $\begin{array}{l}\text { Marked available mixture of } \\
\text { plant residues, husk, coconut } \\
\text { fiber and cow dung }\end{array}$ & $\begin{array}{l}\text { Daily irrigation at } 8.00 \\
\text { and } 16.00 . \\
\text { Fertilizer } 16-16-16 \text { twice in } \\
\text { February and May. }\end{array}$ \\
\hline [17] & GF & - & - & $\begin{array}{l}\text { Momordica charantia, } \\
\text { Ipomoea tricolor, } \\
\text { Canavalia gladiate, Pueraria lobate, } \\
\text { Apios American Medikus }\end{array}$ & & & Akadama soil & \\
\hline [18] & Indirect $G F$ & Open $20 \mathrm{~cm}$ & $\begin{array}{l}\text { Gypsum - alveolar brick-cement } \\
\text { mortar- } U=0.784 \mathrm{~W} / \mathrm{m}^{2} \mathrm{~K}\end{array}$ & Parthenocissus tricuspidata & $3.5-4.0$ & & & $\begin{array}{l}\text { Simple drip irrigation } \\
\text { during summer }\end{array}$ \\
\hline [19] & Direct $G F$ & - & Bricks & Parthenocissus tricuspidata & 1.8 & 12 & & \\
\hline [22] & Indirect $L W$ & Close, $20 \mathrm{~cm}$ & Foam sandwich panel & Vinca Major Varegata & 4.0 & 15 & $\begin{array}{l}\text { Peat soil, powdered perlite, } \\
\text { vermiculite and organic } \\
\text { fertilizer }\end{array}$ & One for day. \\
\hline [31] & Indirect $L W$ & Open 3 to $60 \mathrm{~cm}$. & $U=0.25 \mathrm{~W} / \mathrm{m}^{2} \mathrm{~K}$ & Six plant species not specified & & & Mix of light growth media & $\begin{array}{l}\text { Once a day with an } \\
\text { electrically system }\end{array}$ \\
\hline [33] & Direct $L W$ & - & $\begin{array}{l}\text { Sandwich panels with } \\
\text { polyurethane foam covered by } \\
\text { painted steel sheets in both sides }\end{array}$ & $\begin{array}{l}\text { Sedum album, Sedum sediforme, } \\
\text { Thymus serphyllum, Valgaris, } \\
\text { Prostrates, Mastichina, } \\
\text { Archillea millefolium }\end{array}$ & & & $\begin{array}{l}60 \% \text { organic and } 40 \% \\
\text { inorganic materials }\end{array}$ & $\begin{array}{l}\text { Every two days at 17:00, } \\
\text { between } 4 \text { and } 7 \text { min until the } \\
\text { modules are completely wet. }\end{array}$ \\
\hline [34] & Direct $L W$ & - & Masonry wall & $\begin{array}{l}\text { Achillea millefolia, } \\
\text { Bergenia cordifolia, } \\
\text { Dianthus deltoides, Molinia } \\
\text { caerulea, Nepeta faassenii, Salvia } \\
\text { nemorosa and Sesleria heufleriana }\end{array}$ & & & $\begin{array}{ll}\text { 1. } & \text { Rockwool panelsystem } \\
\text { 2. } & \text { Pumice-filled } \\
& \text { pocket system }\end{array}$ & $\begin{array}{l}\text { Three times for day for } \\
10 \mathrm{~min} \text {. After twice a } \\
\text { day for } 15 \mathrm{~min} \\
\text { 2. Three times a day } \\
\text { for } 10 \mathrm{~min} \text {. } \\
\text { After } 1 \mathrm{~h} \text { every-day. }\end{array}$ \\
\hline [35] & $\begin{array}{ll}\text { 1. } & \text { Indirect } G F \\
\text { 2. } & \text { Indirect } L W\end{array}$ & $\begin{array}{l}\text { 1. Open, } 25 \mathrm{~cm} \\
\text { 2. Open }\end{array}$ & $\begin{array}{l}\text { gypsum - alveolar brick- } \\
\text { cement mortar } \\
U=0.784 \mathrm{~W} / \mathrm{m}^{2} \mathrm{~K}\end{array}$ & $\begin{array}{ll}\text { 1. } & \text { Parthenocissus tricuspidata } \\
\text { 2. } & \text { Rosmarinus officinalis and } \\
\text { Helichrysum thianschanicum }\end{array}$ & & & Coconut fibers & \\
\hline [36] & Direct $G F$ & - & Bricks & Hedera helix & & 10 & & \\
\hline [37] & Direct $G F$ & - & Bricks & $\begin{array}{l}\text { (1) Stachys, (2) Fuchsia, (3) } \\
\text { Jasminum, (4) Hedera, (5) Lonicera, } \\
\text { (6) Prunus }\end{array}$ & $\begin{array}{l}\text { (1) } 4.5, \text {, (2) } 8.0, \\
\text { (3) } 7.0, \text {, (4) } 6.7 \\
\text { (5) } 10.8,(6) 5.2\end{array}$ & & & \\
\hline [38] & Direct $G F$ & - & Plaster - limestone - brick & Parthenocissus tricuspidata & 2.0 & 20 & & \\
\hline
\end{tabular}


Table 1. Cont.

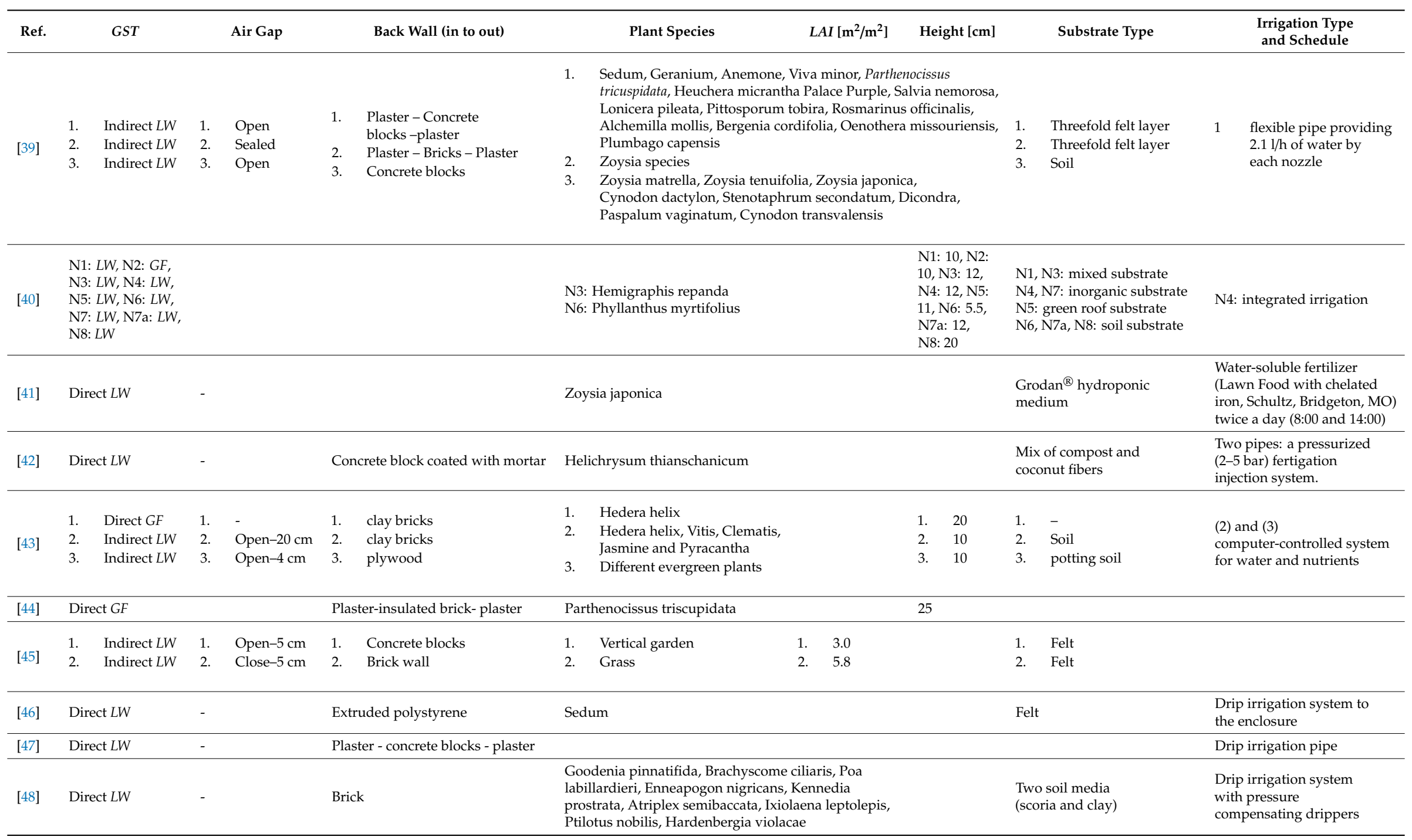


Table 1. Cont.

\begin{tabular}{|c|c|c|c|c|c|c|c|c|}
\hline Ref. & GST & & Air Gap & Back Wall (in to out) & $\operatorname{LAI}\left[\mathrm{m}^{2} / \mathrm{m}^{2}\right]$ & Height $[\mathrm{cm}]$ & Substrate Type & $\begin{array}{l}\text { Irrigation Type } \\
\text { and Schedule }\end{array}$ \\
\hline [49] & $\begin{array}{ll}\text { 1. } & \text { Direct } G W \\
\text { 2. } & \text { Indirect } G W \\
\text { 3. } & \text { Indirect } L W \\
4 . & \text { Indirect } L W\end{array}$ & $\begin{array}{l}1 . \\
2 . \\
3 . \\
4 .\end{array}$ & $\begin{array}{l}\text { No } \\
\text { Open, } 5 \mathrm{~cm} \\
\text { Open, } 5 \mathrm{~cm} \\
\text { Open, } 5 \mathrm{~cm}\end{array}$ & $\begin{array}{l}\text { Bricks -air - mineral wool - } \\
\text { limestone }\end{array}$ & $\begin{array}{ll}\text { 1. } & \text { Hedera helix } \\
\text { 2. } & \text { Hedera helix } \\
\text { 3. } & \text { Pteropsida } \\
\text { 4. } & \text { Pteropsida }\end{array}$ & $\begin{array}{ll}\text { 1. } & 20 \\
2 . & 10 \\
\text { 3. } & 10 \\
\text { 4. } & 10\end{array}$ & $\begin{array}{ll}\text { 1. } & \text { Terrestrial soil } \\
2 . & \text { Terrestrial soil } \\
\text { 3. } & \text { Potting soil } \\
\text { 4. } & \text { Wool fleece }\end{array}$ & \\
\hline [50] & Direct $L W$ & - & & Masonry wall & $\begin{array}{l}\text { Allium schoenoprasum, Chamaecyparis persifera, } \\
\text { Euonymus fortuneii, Ilex crenata, Luzula sylvatica, } \\
\text { Vinca minor, Vaccinium vitis-idea. }\end{array}$ & & $\begin{array}{l}\text { Rockwool panels } \\
\text { (Vertigreen }{ }^{\mathrm{TM}} \text {, Zinco GmbH) }\end{array}$ & $\begin{array}{l}\text { - Three times a day for } \\
10 \mathrm{~min} \text { with a rate of } \\
4.6 \mathrm{~L} / \mathrm{min} \text {. Fertilizer } \\
20 \mathrm{~mL} / \text { panel one week } \\
\text { after planting and in the } \\
\text { beginning of July. } \\
\text { - Three times a day for } \\
10 \mathrm{~min} \text { with a rate of } \\
0.8 \mathrm{~L} / \mathrm{min} \text {. } \\
\text { Evening and morning } \\
\text { for } 15 \mathrm{~min} \text {. }\end{array}$ \\
\hline
\end{tabular}


Finally, it can be concluded that available studies do not present a complete replicable characterization of green vertical systems; there are only a few experimental studies that explicit the base performance parameters or that describe how these have been calculated. Surely, the actual research is not exhaustive in the matter of thermal and bio-physic characteristics.

\subsection{Mathematical Models for the Greening Systems' Performance Evaluation}

Another important question to answer is the shortage of validated simulation models. Indeed, this research area is today under development. A validated model of a $G W$ could help the optimization of design parameters and the evaluation of urban and building benefits as well as it would allow reliable evaluation of the effects on sustainability; the availability of data also allows to increase the awareness of designers and citizens about this technology. Table 2 presents a critical analysis of available mathematical models also evidencing if they have been implemented in commercial simulation engines. In this case, for each paper, it has been deduced the type of tool used, the typology of heat flux, the parameters or index of the validation and the validation data.

Table 2. GW models.

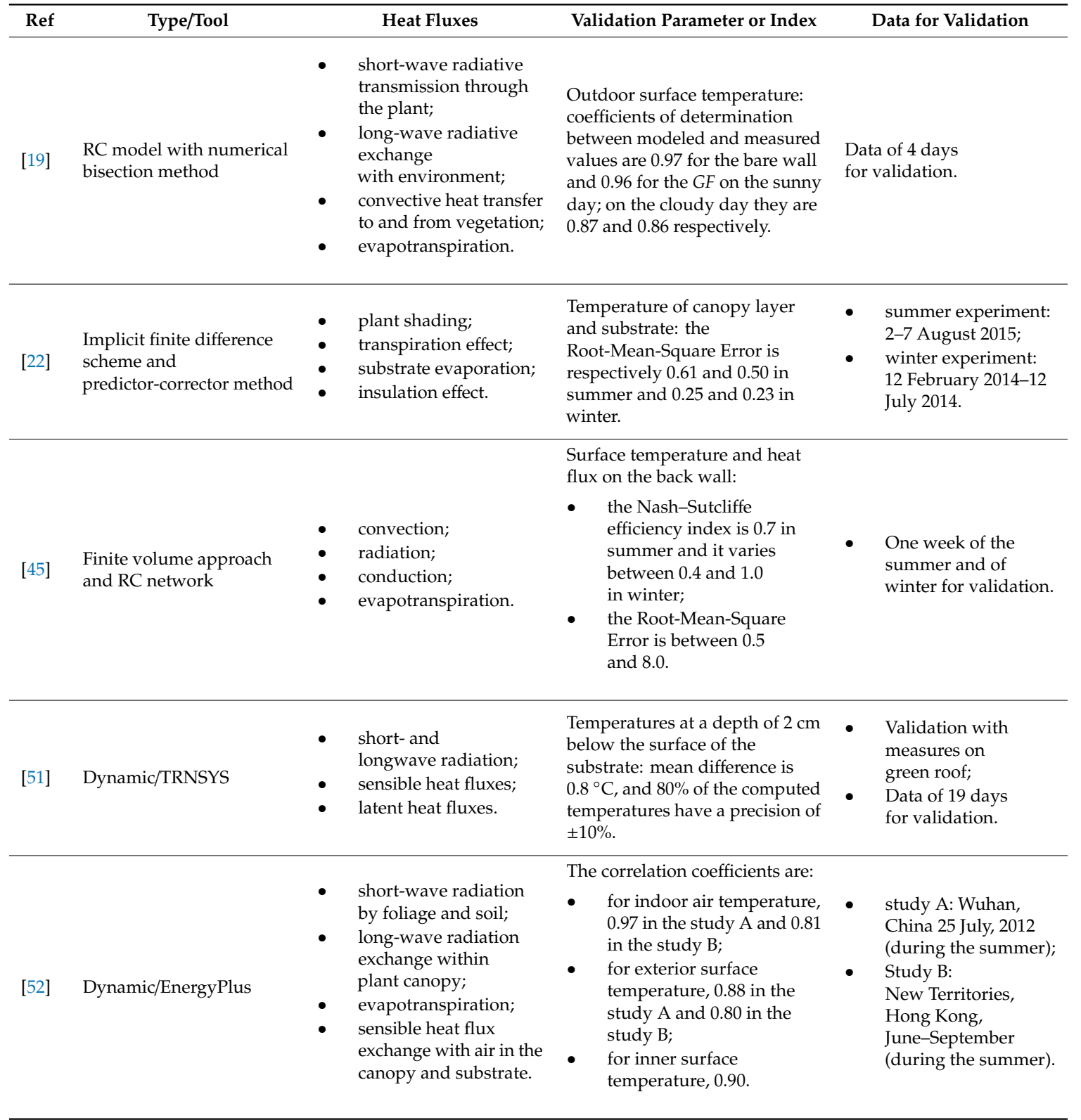


Table 2. Cont.

\begin{tabular}{|c|c|c|c|c|}
\hline Ref & Type/Tool & Heat Fluxes & Validation Parameter or Index & Data for Validation \\
\hline [53] & $\begin{array}{l}\text { 2R3C } \\
\text { model/SOLENE-Microclimate }\end{array}$ & $\begin{array}{l}\text { - } \quad \text { short and long-wave } \\
\text { radiative exchange; } \\
\text { - } \quad \text { evapotranspiration; } \\
\text { - } \quad \text { convection. }\end{array}$ & $\begin{array}{l}\text { Leaf and substrate temperature: } \\
\text { the difference between } \\
\text { measured and simulated values } \\
\text { are lower than } 2{ }^{\circ} \mathrm{C} \text { for sample } 1 \\
\text { and } 2 \text { and lower than } 1^{\circ} \mathrm{C} \text { for } \\
\text { sample } 3 \text {. }\end{array}$ & $\begin{array}{l}\text { Monitoring during May } \\
2009 \text { in Geneva on three of } \\
1 \mathrm{~m}^{2} \text {. }\end{array}$ \\
\hline
\end{tabular}

The most common assumptions made by models are cited in the following bullet list:

- mono-dimensional heat flux;

- constant parameters for describing leaves behavior;

- leaf angles are not considered;

- plants and substrate are homogeneous;

- the biochemical reactions and heat conduction through plants are not taken into account.

Only one paper [19] specifies that the model considers plants only during the growing season, the temperature of a leaf is assumed to be the same as the air temperature, the external factors that may vary with height are assumed to be constant, the level of soil moisture at plant roots is constant. These limitations, by considering the proposed equations, probably affect also other models that, analogously, also consider these parameters as constant.

Susurova et al. [19] have proposed a model focused on plant physiological processes, including evapotranspiration and radiative and convective heat exchanges interesting the plant layer, the facade, the surrounding environment and the ground: the model takes into account individual plant characteristics inputs and weather data; it should be noted, furthermore, that this model has been verified with a set of experiments that measured thermal performance of both bare and vegetated facade of an educational building in Chicago, during the summer. Scarpa et al. [46] have defined a mathematical model validated against in-field measurements for two different kinds of $L W s$, with open or closed air cavities, monitored in Central and Northern Italy. Djedjig et al. [51] have developed a model for the evaluation of the coupled heat and mass transfers through a green module that, in addition to a street canyon model, was integrated into TRNSYS code [54]. He et al. [22] have developed a model that evaluates the one-dimensional distribution of temperature and moisture. The main assumptions are: constant wind speed along the height direction; constant water content distribution under daily irrigation, ignoring gravity effect and precipitation; plant canopy is considered as a semi-transparent medium. The model has been validated with in-field experiments carried out on two test rooms in the Jiading campus. In 2017 Dahanayake et al. [52] proposed the integration of a mathematical model based on heat balance principle of the foliage layer and soil layer in EnergyPlus, basing on the equations of the green roof module. The model has been validated by means of two experimental studies. A hydro-thermal model of GWs has been carried out by Malys et al. [53] for the implementation in the urban microclimate simulation software SOLENE-Microclimate. Kontoleon and Eumorfopoulou [32] have modeled the behavior of a building zone with a $G W$ by employing a RC-network model with transient nodal solution, which allows the adjustment of the various parameters in discrete time steps. The following mechanisms are taken into account: conduction, convection and radiation through envelope, heat storage within the thermal mass, heat transfer mechanisms through the foliage canopy. The model allows to take into account the wall orientation, the covering percentage of plant foliage, and the type of wall configuration. However, validation indexes are not proposed, and the reliability of the model cannot be discussed. Finally, basing on experimental data, Olivieri et al. [55] have developed an autoregressive fitted model that allows the prediction of temperature difference between a module without vegetation and a module with vegetation, by using as input values only outdoor climate conditions: temperature, relative humidity and the vertical irradiance on the surface.

The previous analysis allows concluding that some mathematical models are available, but these are not already implemented in commercial software, not validated according to standard procedures 
and these are not easily adoptable by designers and researchers for studying thermal and energy performances of $G W$ systems.

Often, simulation tools, e.g., EnergyPlus, have implemented merely a module for simulating green roof, specifically validated for surfaces with low inclinations. As asserted by some studies [56], this module can predict, approximately, the behavior also of green vertical walls, although the results have not been validated by the developers. The main difference is the great amount of water held by the roof compared to the wall but also the dynamics of hydro-thermal mechanisms on a vertical (and thus not horizontal) surface.

\section{A Critical Overview of Vertical Greening Systems' Performances}

GWs and LWs are investigated and reviewed according to several points of view. At the building level, the most studied effects of vertical green systems are:

- reduction of heating and cooling energy demand,

- improvement of thermal comfort,

- noise reduction,

- $\quad$ protection of the exterior coatings from $U V$ radiation or extreme weathering.

Moreover, several aspects can be underlined about the urban rehabilitation: the reduction of urban heat island (UHI) effect, the improvement of storm-water management and the absorption of air pollutants in the atmosphere. In addition, building greenery allows to increase the vegetation in the urban context without occupying any space at street level and to enhance the biodiversity with the indirect improvement of urban image. This section proposes a critical analysis of available research results, distinguishing the behavior of green vertical systems in three main areas: urban quality, building performance and sustainability.

\subsection{Urban Quality}

Considering the available studies, the most measured parameter is the reduction of surface temperature between the bare wall and the green coverage. This can be related to potentialities in terms of $U H I$ mitigation due to spectral characteristics of plants that determine a selective absorption of heat wave radiation and the reduction of re-radiation, but it is also related to the cooling effect of urban space and the reduction of building energy need during the summer. This surface temperature is usually measured by means of an infrared camera or with surface temperature sensors.

Really, it has to be underlined that many studies compare the monitored temperature on the bare wall and the values at the same point when the wall is covered by a green layer and therefore the temperature measure is not on the substrate or on the leaves. This kind of measure cannot be considered useful for the evaluation of urban heat island mitigation and surface temperature reduction. Really, it can give information about the energy saving also if, often, it is not possible to distinguish the contribution of vegetation mechanism and the air gap (usually present) effect. For instance, two studies have been done in the Mediterranean climate [39,57]; according to these, the external surface temperature difference between the bare wall and the covered wall goes from $9{ }^{\circ} \mathrm{C}$ (Pandorea jasminoides variegated and Rhyncospermum jasminoides) to $20^{\circ} \mathrm{C}$ (threefold felt layer with evergreen or seasonal plants), during sunny days.

Table 3 summarizes only the results of reviewed papers that consider the temperature difference between the bare wall and the substrate/foliage. For each paper, the way through which results have been achieved is evidenced. In particular, the following nomenclature is adopted: Exp = experimental and Num = numerical. The climatic zones are named according to Köppen-Geiger classification, and other considered parameters are the observation period, the vegetation species as well as the type of green vertical system, the orientation and the average or maximum value of external surface temperature reduction. A star $\left(^{*}\right)$ near the value means that this has been obtained with some elaborations. 
Table 3. Results about surface temperature reduction (please, note that GF is Green Façade, LW is Living Wall, N stands for configuration, 1. and 2. are used when two different GST are investigated).

\begin{tabular}{|c|c|c|c|c|c|c|c|}
\hline Ref & Type & Climate & Period & Plant Species & GST & Orientation & $\begin{array}{c}\text { External Surface } \\
\text { Temperature Reduction }\end{array}$ \\
\hline \multirow[b]{2}{*}{ [16] } & \multirow[b]{2}{*}{ Exp. } & \multirow[b]{2}{*}{$\begin{array}{l}\text { Phitsanulok (Aw or As - Tropical wet } \\
\text { and dry or savanna climate) }\end{array}$} & \multirow[b]{2}{*}{$\begin{array}{l}\text { December 2015- } \\
\text { May } 2016\end{array}$} & \multirow[b]{2}{*}{$\begin{array}{l}\text { False Heather, Princess Flower, } \\
\text { Chinese Croton }\end{array}$} & \multirow[b]{2}{*}{$L W$} & \multirow[b]{2}{*}{ South } & Average values \\
\hline & & & & & & & $\begin{array}{l}\text { - Summer: Day: } 1.6^{\circ} \mathrm{C} \text {, Night: } 0.73^{\circ} \mathrm{C} \\
\text { - Winter: Day: } 2.6^{\circ} \mathrm{C} \text {, Night: } 1.15^{\circ} \mathrm{C}\end{array}$ \\
\hline \multirow[b]{2}{*}{ [22] } & \multirow[b]{2}{*}{ Exp. } & \multirow[b]{2}{*}{$\begin{array}{l}\text { Shanghai (Cfa - Humid subtropical } \\
\text { climate) }\end{array}$} & & \multirow[b]{2}{*}{ Vinca Major Varegata } & \multirow{2}{*}{\multicolumn{2}{|c|}{$L W$}} & Maximum values \\
\hline & & & $\begin{array}{l}\text { August } 2015 \\
\text { December } 2015\end{array}$ & & & & $\begin{array}{l}\text { - Summer: Day: } 28^{\circ} \mathrm{C} \text {, Night: }-2^{\circ} \mathrm{C} \\
\text { - Winter: Day: } 10^{\circ} \mathrm{C} \text {, Night: }-10^{\circ} \mathrm{C}\end{array}$ \\
\hline \multirow[b]{2}{*}{ [32] } & \multirow[b]{2}{*}{ Num. } & \multirow[b]{2}{*}{$\begin{array}{l}\text { Thessaloniki (Cfa - Humid } \\
\text { subtropical climate) }\end{array}$} & \multirow[b]{2}{*}{ June-August } & \multirow[b]{2}{*}{ Parthenocissus triscupidata } & \multirow[b]{2}{*}{ GF } & & Average values \\
\hline & & & & & & $\begin{array}{l}\text { North } \\
\text { East } \\
\text { South } \\
\text { West }\end{array}$ & $\begin{array}{l}\text { - } \quad \text { North: } \approx 2.73^{\circ} \mathrm{C}^{*} \\
\text { - } \quad \text { East: } \approx 11.53^{\circ} \mathrm{C}^{*} \\
\text { - } \quad \text { South. } \approx 7.46^{\circ} \mathrm{C}^{*} \\
\text { - } \quad \text { West: } \approx 17.85^{\circ} \mathrm{C}^{*}\end{array}$ \\
\hline [33] & Exp. & $\begin{array}{l}\text { Covilhã (Csb - Warm summer } \\
\text { Mediterranean climate) }\end{array}$ & February-March & Sedum species and Thymus species & $L W$ & South & Maximum value: $15^{\circ} \mathrm{C}$ \\
\hline [35] & Exp. & $\begin{array}{l}\text { Puigverd de Lleida (Csa - } \\
\text { Hot-summer Mediterranean climate) }\end{array}$ & June-JulyDecember-February & $\begin{array}{ll}\text { 1. } & \text { GF: Boston Ivy - } \\
\text { Parthenocissus tricuspidata } \\
\text { 2. } L W: \text { Rosmarinus officinalis and } \\
\text { Helichrysum thianschanicum }\end{array}$ & $\begin{array}{l}1 . \\
2 .\end{array}$ & $\begin{array}{ll}\text { - } & \text { East } \\
\text { - } & \text { South } \\
\text { - } & \text { West }\end{array}$ & $\begin{array}{l}\text { Average values } \\
\text { - Summer: } \\
\text { East: } L W 17.0^{\circ} \mathrm{C} ; G F 13.8^{\circ} \mathrm{C} \\
\text { South: } L W 21.5^{\circ} \mathrm{C} ; G F 10.7^{\circ} \mathrm{C} \\
\text { West: } L W 20.1^{\circ} \mathrm{C} ; G F 13.9^{\circ} \mathrm{C} \\
\text { - Winter: } \\
\text { East: } L W 4.5^{\circ} \mathrm{C} ; G F-0.2^{\circ} \mathrm{C} \\
\text { South: } L W 16.5^{\circ} \mathrm{C} ; G F 0.7^{\circ} \mathrm{C} \\
\text { West: } L W 6.5^{\circ} \mathrm{C} ; G F-0.3^{\circ} \mathrm{C}\end{array}$ \\
\hline [36] & Exp. & $\begin{array}{l}\text { Nottingham }(\mathrm{Cfb} \text { - Temperate } \\
\text { oceanic climate) }\end{array}$ & 3 weeks & Hedera helix & GF & & $\begin{array}{l}\text { Maximum value } \\
6.1^{\circ} \mathrm{C} \text { on sunny days and } 4.0^{\circ} \mathrm{C} \text { on } \\
\text { cloudy days }\end{array}$ \\
\hline
\end{tabular}


Table 3. Cont

\begin{tabular}{|c|c|c|c|c|c|c|c|}
\hline Ref & Type & Climate & Period & Plant Species & $G S T$ & Orientation & $\begin{array}{c}\text { External Surface } \\
\text { Temperature Reduction }\end{array}$ \\
\hline [37] & Exp. & $\begin{array}{l}\text { Reading (Cfb - Temperate oceanic } \\
\text { climate) }\end{array}$ & 19 August & Prunus laurocerasus & GF & South & Average value: $6.3^{\circ} \mathrm{C}$ \\
\hline [40] & Exp. & $\begin{array}{l}\text { Singapore (Af - Tropical rainforest } \\
\text { climate) }\end{array}$ & $\begin{array}{l}24 \text { February 2008, } \\
\text { 28 April } 2008 \\
\text { 21 June } 2008\end{array}$ & $\begin{array}{l}\text { N3: } L W \text { Hemigraphis repanda } \\
\text { N6: } L W \text { Phyllanthus myrtifolius }\end{array}$ & $\begin{array}{l}\text { N1: } L W, \\
\text { N2: } G F, \\
\text { N3: } L W, \\
\text { N4: } L W, \\
\text { N5: } L W, \\
\text { N6: } L W, \\
\text { N7: } L W, \\
\text { N7a: } L W, \\
\text { N8: } L W\end{array}$ & & $\begin{array}{l}\text { Maximum value } \\
\text { - 24/02: N1:5.23 }{ }^{\circ} \mathrm{C}, \mathrm{N} 2: 2.45^{\circ} \mathrm{C}, \\
\text { N3: } 4.92^{\circ} \mathrm{C}, \mathrm{N} 4: 5.30^{\circ} \mathrm{C}, \\
\text { N5: } 4.48^{\circ} \mathrm{C}, \mathrm{N} 6: 3.25^{\circ} \mathrm{C}, \\
\text { N7: } 4.25^{\circ} \mathrm{C}, \mathrm{N} 8: 3.72^{\circ} \mathrm{C} \\
\text { 28/04: N1: } 7.93^{\circ} \mathrm{C}, \mathrm{N} 2: 7.32^{\circ} \mathrm{C} \text {, } \\
\text { N3: } 9.211^{\circ} \mathrm{C}, \mathrm{N} 4: 8.95^{\circ} \mathrm{C}, \\
\text { N5: } 8.488^{\circ} \mathrm{C}, \mathrm{N} 6: 6.11^{\circ} \mathrm{C}, \\
\text { N7a: } 6.12^{\circ} \mathrm{C}, \mathrm{N} 8: 7.84^{\circ} \mathrm{C} \\
\text { 21/06: N1: } 5.33^{\circ} \mathrm{C}, \mathrm{N} 2: 6.35^{\circ} \mathrm{C} \text {, } \\
\text { N3: } 5.69^{\circ} \mathrm{C}, \mathrm{N} 4: 6.34^{\circ} \mathrm{C}, \\
\text { N5: } 6.53^{\circ} \mathrm{C}, \mathrm{N} 6: 4.04^{\circ} \mathrm{C}, \\
\text { N7a: } 4.97^{\circ} \mathrm{C}, \mathrm{N} 8: 6.61^{\circ} \mathrm{C}\end{array}$ \\
\hline [44] & Exp. & $\begin{array}{l}\text { Thessaloniki (Cfa - Humid } \\
\text { subtropical climate) }\end{array}$ & July-August 2006 & Parthenocissus triscuspidata & GF & East & $\begin{array}{l}\text { Average value: } 5.7^{\circ} \mathrm{C} \\
\text { Maximum value }<8.10^{\circ} \mathrm{C}^{*}\end{array}$ \\
\hline [48] & Exp. & $\begin{array}{l}\text { Mawson Lakes (Csb - Warm-summer } \\
\text { Mediterranean climate) }\end{array}$ & $\begin{array}{l}\text { December 2014- } \\
\text { July } 2015\end{array}$ & $\begin{array}{l}\text { Goodenia pinnatifida, Brachyscome } \\
\text { ciliaris, Poa labillardie, Enneapogon } \\
\text { nigricans, Kennedia prostrata, } \\
\text { Atriplex semibaccata, Ixiolaena } \\
\text { leptolepis, Ptilotus nobilis, } \\
\text { Hardenbergia violacae }\end{array}$ & $L W$ & West & $\begin{array}{l}\text { Average values } \\
\text { - Warm days: Day: } 3.4^{\circ} \mathrm{C}^{*} \text {, } \\
\text { Night: } 1.9^{\circ} \mathrm{C}^{*} \\
\text { - } \quad \text { Cold days: Day } 0.22{ }^{\circ} \mathrm{C}^{*} \text {, } \\
\quad \text { Night: }-0.05^{\circ} \mathrm{C}^{*} \\
\text { Maximum values } \\
\text { - } \quad \text { Warm days: } 14.90^{\circ} \mathrm{C} \\
\text { - } \quad \text { Cold days: }-5.88^{\circ} \mathrm{C}\end{array}$ \\
\hline
\end{tabular}


Table 3. Cont

\begin{tabular}{|c|c|c|c|c|c|c|c|}
\hline Ref & Type & Climate & Period & Plant Species & $G S T$ & Orientation & $\begin{array}{c}\text { External Surface } \\
\text { Temperature Reduction }\end{array}$ \\
\hline [52] & Num. & $\begin{array}{l}\text { Hong Kong and Wuhan } \\
\text { (Cfa - Humid subtropical climate) }\end{array}$ & $\begin{array}{l}\text { one hottest summer day } \\
\text { one coldest winter day }\end{array}$ & $\begin{array}{l}\text { 1. Peperomia claviformis } \\
\text { 2. Plant not specified }\end{array}$ & $\begin{array}{ll}\text { 1. } & L W \\
\text { 2. } & L W\end{array}$ & $\begin{array}{ll}\text { 1. } & \text { Exposure } \\
\text { not specified } \\
\text { 2. } & \text { West }\end{array}$ & $\begin{array}{l}\text { Hong Kong maximum values } \\
\text { - Hottest summer day: } 24.2^{\circ} \mathrm{C} \\
\text { - } \quad \text { Coldest winter day: } 16.9^{\circ} \mathrm{C} \\
\text { Wuhan maximum values } \\
\text { - } \quad \text { Hottest summer day } 26.2^{\circ} \mathrm{C} \\
\text { - } \quad \text { Coldest winter day: } 18.4^{\circ} \mathrm{C}\end{array}$ \\
\hline [53] & Exp. & $\begin{array}{l}\text { Geneva (Cfb - Temperate } \\
\text { oceanic climate;) }\end{array}$ & $\begin{array}{l}\text { May } \\
\text { (1 week) }\end{array}$ & & $L W$ & South & Maximum value: $13{ }^{\circ} \mathrm{C}^{*}$ \\
\hline [58] & Exp. & $\begin{array}{l}\text { Santiago of Chile (Csb - } \\
\text { Warm-summer } \\
\text { Mediterranean climate) }\end{array}$ & January (12 days) & $\begin{array}{l}\text { Highly dense sedum, medium dense } \\
\text { sedum }\end{array}$ & $L W$ & North & Maximum value: $30^{\circ} \mathrm{C}$ \\
\hline
\end{tabular}


Briefly, 13 papers published in indexed international journals during last 10 years have been found; the highest percentage (85\%) refers to experimental studies. Among these, only two studies carried out a monitoring campaign for six months at least. Globally, data are incomparable because these are very different in terms of climate, exposure and monitoring/simulation periods and, therefore, it is not possible to create a unique forecast scenario. However, the data reported in the table suggest some interesting general conclusions. These are here briefly reported.

First of all, the $L W$ is more studied compared with GF but only two papers [35,40], for different climates, compare their behavior in the same conditions. Then, it can be observed that, during the summer, the $L W$ assures, for each exposure, the highest reduction of temperature with better results on the south side. The results are not so obvious for a tropical climate because for some conditions the GF works better than $L W$.

The $L W s$ are characterized by major temperature reduction, for chosen conditions, with highest values $\left(\approx 30^{\circ} \mathrm{C}\right)$ in warm-summer Mediterranean climate and humid subtropical climate. It can be concluded that LWs seem to be more effective in terms of surface temperature reduction due to shading and evapotranspiration effects, also favored by the substrate that increases also the surface mass of the walls. Hence, there is a potential of $L W$ s to face the UHI phenomena.

Moreover, there is not a general conclusion about the effectiveness of some plant species for $L W$. The increment of leaf index has a positive effect on the reduction of surface temperature as well as the adoption of evergreen plants. Some general considerations about the plants for GF can be found. The greatest temperature reductions are observed on the points where the foliage is thicker and more intensive, and closer to the ground where the evaporative cooling is dominant [32]. Hedera and the silver-leaved, semi-herbaceous Stachys might be the best species for temperate oceanic climate; however, Cameron et al. [37] suggested that, if the other species increase their canopy density during the growing, they may provide better cooling potential, particularly if they are well irrigated with the aim to maintain consistent the evapotranspiration. Similarly, for humid subtropical climate, Kontoleon et al. [32] have shown that, when the covering percentage of the plant foliage increases, there is an improvement of their behavior.

The effect of orientation is clear for GF; when the same configuration is compared on different exposures, the exposures for maximizing the cooling effect are the West and the East ones. For $L W$, the best orientation seems to be the south and very often this is the selected exposure for experimental and numerical studies. However, this is not always true. Indeed, the paper [22], by means of a validated heat and moisture transfer numerical model, shows that, for the climate of Shanghai, without any shading from other surrounding buildings, the preference sequence is West $\rightarrow$ East $\rightarrow$ South $\rightarrow$ North.

More recently, to study the influence of vegetated wall on UHI problem, Feitosa and Wilkinson [59] have adopted the heat index $(H I)$ that combines the effect of air temperature and relative humidity. They have compared two houses, one of these fully covered with vegetation, in two cities: Rio de Janeiro (Brazil) and Sydney (Australia). For Rio de Janeiro, they have not recorded HI higher than 15 ${ }^{\circ} \mathrm{C}$ and the occurrences were $1.4 \%$ and $14.9 \%$, respectively between $10{ }^{\circ} \mathrm{C}$ and $15{ }^{\circ} \mathrm{C}$, and $5{ }^{\circ} \mathrm{C}$ to $10{ }^{\circ} \mathrm{C}$. For the case study in Sydney, $\mathrm{HI}$ attenuation between $15^{\circ} \mathrm{C}$ and $20^{\circ} \mathrm{C}$ has been observed over $0.7 \%$ of the duration of the experiment; the frequency between $10^{\circ} \mathrm{C}$ and $15^{\circ} \mathrm{C}$ has been $1.8 \%$ and equal to $4.1 \%$ of the time for the temperature range from $5{ }^{\circ} \mathrm{C}$ to $10^{\circ} \mathrm{C}$. Another approach has been presented by Herath et al. [60]; they have compared, by means of simulations, the outdoor air temperature at a height of $1.5 \mathrm{~m}$ with the measured real ground temperature values. This evaluation has been done in a tropical warm humid area (Sri Lanka). The temperature reduction has been of $2.03^{\circ} \mathrm{C}$ for the scenario with GWs (100\% of total wall area) in East-West orientation, neighboring buildings on three sides and asphalt road from one side. Moreover, the temperature reduction was of about $1.59^{\circ} \mathrm{C}$ when there are neighboring buildings on two sides, asphalt road from one direction.

For tropical climate, the paper [40] takes into account the measurement of air temperature at intervals of $0.15 \mathrm{~m}, 0.30 \mathrm{~m}, 0.60 \mathrm{~m}$ and $1.00 \mathrm{~m}$ away from the substrate surface, during the 1st December 2008, with 8 different vertical greenery systems installed in HortPark (Singapore). The GF type does not 
influence the ambient temperature while the $L W$ number 4 is felt as far as $0.60 \mathrm{~m}$ away with maximum reduction value of $3.33^{\circ} \mathrm{C}$ at a distance of $0.15 \mathrm{~m}$. According to the authors, their results demonstrate the highest potentialities of $L W s$ to cool the ambient temperature in building canyons.

The study of Razzaghmanesh et al. [48] has pointed out that the difference between recorded temperatures cannot be considered significant in warm-summer Mediterranean climates. More in detail, during the warm scenario, at $0.50 \mathrm{~m}$ away from the bare and $L W$, the temperature is almost the same in most hours; the temperature in front of the bare wall is warmer from 2:30 p.m. to 6:30 p.m., with the maximum difference of $1.68^{\circ} \mathrm{C}$. In a further study, by considering summer conditions in Berlin, with measured data on GFs with three different climbing plants (Parthenocissus tricuspidata, Hedera helix and Fallopia baldschuanica), Hoelscher et al. [61] have asserted that a cooling effect for the ambient air in the street canyon is not assured although the difference between external surface temperatures of green and not covered walls were up to $15.5^{\circ} \mathrm{C}$. Analogously, for the GW of the Caixa Forum Museum (Madrid, Spain), summer experimental activities have demonstrated that the air temperature reduction varies between $2.5^{\circ} \mathrm{C}$ and $2.9^{\circ} \mathrm{C}$ [62].

Finally, Susorova et al. [38] have shown that, in a cold climate, during the summer days, compared to values near the bare walls, the outdoor air temperature near the vegetated facade is on average $0.8-2.1^{\circ} \mathrm{C}$ lower (depending on orientation), the relative humidity is $2-4 \%$ higher and the air velocity is $18-3 \%$ lower.

Another investigated effect is air pollution control. Marchi et al. [63], using a dynamic simulation model, have shown that a $L W$ of $98 \mathrm{~m}^{2}$, placed in central Italy, can capture, averagely, a carbon dioxide flow of 13.4-97.0 $\mathrm{kg} \mathrm{CO}_{2 \text { eq }}$ per year. Considering a mixed green cover of different plant species, the authors have estimated an average carbon dioxide flow of $60.87 \mathrm{~kg} \mathrm{CO}_{2 \text { eq }}$ per year. Othman and Kasim [64] have pointed out that the carbon sequestrated by individual creepers and climbers ranges from 30 to $170 \mathrm{~kg} \mathrm{CO}$ eq per year. Charoenkit and Yiemwattana [16] have found that the carbon content of $L W$ s decreased by $50 \%$ in six months, indicating a lack of capacity in carbon sequestration. In particular, this decrement has been found only in the substrate, due to the extraction of nutrients by plants and to the absence of decomposed plants, while the plants had a higher amount of carbon. Considering $L W$ plants alone, the amount of carbon sequestrated ranges from 4.35 to $30.26 \mathrm{~g} \mathrm{CO}_{2} / \mathrm{m}^{2}$. Among three plant species, C. hyssopifola H.B.K (small leaves) had the highest amount of carbon content, followed by E. cochinchinensis and T. urvilleana. More recently, Paull et al. [65] have presented the results of some morphological, physiological, and biochemical tests on eight common GW plant species, before and after exposure of 5 weeks to highly concentrated diesel fuel combustion effluent. They have concluded that the fig family is the most tolerant species.

The benefits in terms of storm-water management are not been evidenced with experiments in the available scientific literature meanwhile few papers evaluate if a $G W$ can work as water treatment systems [66-68]. The aim is to reach an acceptable quality of treated wastewater so that it can be used for building uses and irrigation. Prodanovic et al. [66] have tested some suitable media and it has resulted that slow media have higher performances because these can remove around $90 \%$ of total suspended solids (TSS), $50 \%$ of total nitrogen (TN), 30\% of total phosphorus (TP), $70 \%$ of chemical oxygen demand (COD) and $80 \%$ of Escherichia coli (E. coli). On the other hand, it has been observed that fast media can remove averagely $80 \%, 30 \%, 15 \%, 30 \%$ and $20 \%$ of TSS, TN, TP, COD and E. coli respectively. Perlite was found to have the best hydraulic and treatment performance among the fast media while coco coir was the best slow media. Then, the same authors [67] have studied the effect of percentage variation of coco coir and perlite in the filter media mix on the performance of GWs as a passive greywater treatment system. It is clear that available studies are mainly focused on the evaluation of the impact of greywater on vegetation and these do not quantify the benefit in terms of urban and building management.

Another aspect that can be underlined is the adoption of GWs for reestablishing the habitats for some species; since the modern cities are dominated by the built environment, this has determined the loss of many species [69,70]. About it, Francis and Lorimer [71] have discussed the potential of 
green vertical systems for the reconciliation ecology, intended as the modification of the environment to promote the preservation of biodiversity and, more in general, the non-human use, without compromising the social utilization. This could be the right approach for the restoration, in a new ecological key, of urban areas. In the same vein, Chiquet et al. [72] have found benefits for nesting, food and shelter resources for urban ornithology. The correct design of vertical greening system [73] is, therefore, deliberate manipulation of the habitat template, in order to maximize vegetation cover for visual relief, building energy savings, or other.

Using the city of Southampton as a case study, Collins et al. [74] have estimated the public's perceived value of GWs to urban biodiversity, in the form of their "willingness to pay" (WTP). More in deep, $L W$ and GF designs have been compared against 'no green policy'. In this study, a higher level of WTP was associated with the $L W$. Attitudinal characteristics such as knowledge of biodiversity and aesthetic opinion were significant to determine the value of the greening policies higher than the estimated investment cost.

A quite interesting topic, non-completely investigated, is the economic effect due to vegetation on property value. Briefly, Gao and Asami [75], employing hedonic pricing of greenery, have estimated that an increase in greenery quality level would increase the land price by $1.4 \%$ in Tokyo and by $2.7 \%$ in Kitakyushu. Des Rosiers et al. [76] have estimated that hedges or GWs increase 3.9\% the property value.

As it can be seen, the last part of the analysis regarding the effect on urban quality allows evidence that there are few papers about carbon sequestration potentialities of a GW (compared with green roof). Analogously, there are even fewer papers about the increasing of urban biodiversity or storm-water management as well as of the economic value of the building. This poor information does not allow general conclusions. Thus, scientific research should be improved in these fields for a complete characterization of the urban impact of green vertical systems.

\subsection{Building Performance}

\subsubsection{Energy Savings}

Several papers are focused on the energy saving evaluation. These have been classified in Table 4, by considering the main aspects related to performance calculation. Indeed, it is reported the green system type differentiating "direct" configuration, if the green or the substrate are in full contact with the wall, and "indirect" one if there is an air gap between green/substrate and back wall.

The climate and the calculation or monitoring periods have been indicated as well as the type of application in terms of exposure. Finally, the temperature set-point value is indicated, as well as the global energy saving achieved. For a better reading, please note that a star near the value means that it has been obtained with author elaboration.

Only five papers are based on the experimental approach and the other ones calculate the energy saving by implementing models (more or less accurate) with different simulation programs.

Some comparisons can be done considering the experimental results. The GFs in Mediterranean climates have limited potential in terms of electricity reduction during the summer period. Indeed, for a GF covering approximately $50 \%$ of the south facade of a cubicle made of alveolar brick without insulation, with maximum outside temperatures between $37^{\circ} \mathrm{C}$ and $39^{\circ} \mathrm{C}$, the energy saving for one week in July (2011) is 5.5\% [77]. For the same conditions [18] but considering the application on three exposures of Boston ivy species, during summer 2015, with a higher foliage development $(L A I \approx 3.5-4)$, the declared energy saving during one week of August is $36 \%$. Starting from the data reported by the authors, the daily energy-saving varies between $29 \%$ to $52 \%$. More in general, for GFs, it can be concluded that the energy-saving increases with the LAI (leaf area index); moreover, the configuration that seems to maximize the shadow effect - and thus the energy benefit - consists in the installation of plants on the south, east and west exposures. The comparison for LWs is not possible because only few experimental studies are available and these refer to different climatic conditions. 
Table 4. Results about energy saving.

\begin{tabular}{|c|c|c|c|c|c|c|c|c|}
\hline Ref & Type & Climate & GST & Plant Species & Application & Period & Indoor & Energy Saving \\
\hline [18] & Exp. & $\begin{array}{l}\text { Puigverd de Lleida } \\
\text { (Csa - Hot-summer } \\
\text { Mediterranean climate) }\end{array}$ & Indirect $G F$ & $\begin{array}{l}\text { Boston Ivy - Parthenocissus } \\
\text { tricuspidata }\end{array}$ & $\begin{array}{l}\text { East, south and west } \\
\text { façades of a test room }\end{array}$ & $\begin{array}{l}\text { One week of } \\
\text { August } 2015\end{array}$ & $T_{\text {set-poit }}: 24^{\circ} \mathrm{C}$ & $34 \%$ \\
\hline [31] & Exp. & $\begin{array}{l}\text { Wuhan (Cfa - Humid } \\
\text { subtropical climate) }\end{array}$ & Indirect $L W$ & & $\begin{array}{l}\text { One façade west } \\
\text { oriented of a test cell }\end{array}$ & $\begin{array}{l}\text { One day of } \\
\text { cooling period }\end{array}$ & $T_{\text {set-poit }}: 24^{\circ} \mathrm{C}$ & $11.8 \%$ * \\
\hline [32] & Num. & $\begin{array}{l}\text { Thessaloniki } \\
\text { (Cfa - Humid Subtropical Climate) }\end{array}$ & Direct GF & Parthenocissus triscupidata & $\begin{array}{l}\text { Exposures } \\
\text { singularly valuated }\end{array}$ & One summer day & $\begin{array}{l}T_{\text {set-poit }}: 20{ }^{\circ} \mathrm{C} \\
(8: 00-20: 00)\end{array}$ & $\begin{array}{l}\text { North: } 4.18-4.98 \% \text { * } \\
\text { East: } 16.05-19.45 \% \text { * } \\
\text { South: } 6.69-8.30 \% \text { * } \\
\text { West: } 17.76-21.51 \% \text { * }\end{array}$ \\
\hline [35] & Exp. & $\begin{array}{l}\text { Puigverd de Lleida } \\
\text { (Csa - Hot-summer } \\
\text { Mediterranean climate) }\end{array}$ & $\begin{array}{l}\text { Indirect } G F \\
\text { Indirect } L W\end{array}$ & $\begin{array}{l}\text { GF: Boston Ivy - } \\
\text { Parthenocissus tricuspidata } \\
\text { LW: Rosmarinus and } \\
\text { Helichrysum } \\
\text { thianschanicum }\end{array}$ & $\begin{array}{l}\text { East, south and west } \\
\text { façades of a test room }\end{array}$ & $\begin{array}{l}\text { Cooling: } \\
18^{\circ} \mathrm{C}: 10 \text { days } \\
21^{\circ} \mathrm{C}: 11 \text { days } \\
24^{\circ} \mathrm{C}: 12 \text { days } \\
\text { Heating: } \\
26 \text { days }\end{array}$ & $\begin{array}{l}\text { Cooling period: } \\
T_{\text {set-poit }}: 18^{\circ} \mathrm{C} \\
T_{\text {set-poit }}: 21^{\circ} \mathrm{C} \\
T_{\text {set-poit }}: 24^{\circ} \mathrm{C} \\
\text { Heating period: } \\
T_{\text {set-poit }}: 22^{\circ} \mathrm{C}\end{array}$ & $\begin{array}{l}\text { - Cooling period: } \\
18^{\circ} \mathrm{C}: L W 31.16 \% ; \\
\text { GF } 5.01 \% \\
21^{\circ} \mathrm{C}: L W 42.93 \% ; \\
G F 20.32 \% \\
24^{\circ} \mathrm{C}: L W 58.94 \% ; \\
\text { GF } 33.83 \% \\
\text { - } \quad \text { Heating period: } \\
\text { LW } 4.2 \% ; G F 1.9 \%\end{array}$ \\
\hline [47] & Num. & $\begin{array}{l}\text { Al-Ain City } \\
\text { (Bwh - Hot desert climates) }\end{array}$ & Direct $L W$ & & $\begin{array}{l}\text { East-façade of a } \\
\text { test room }\end{array}$ & One year & $\begin{array}{l}T_{\text {set-poit }}: 25^{\circ} \mathrm{C} \\
\text { Inf:: } 0.5 \mathrm{ACH}\end{array}$ & $20.5 \%$ \\
\hline [52] & Num. & $\begin{array}{l}\text { Hong Kong } \\
\text { Wuhan } \\
\text { (Cfa - Humid subtropical climate) }\end{array}$ & Direct $L W$ & & $\begin{array}{l}\text { One façade of a flat of } \\
\text { a building }\end{array}$ & One year & $\begin{array}{l}\text { Cooling period } \\
T_{\text {set-poit }}: 24^{\circ} \mathrm{C} \\
\text { Heating period } \\
T_{\text {set-poit }}: 20^{\circ} \mathrm{C}\end{array}$ & 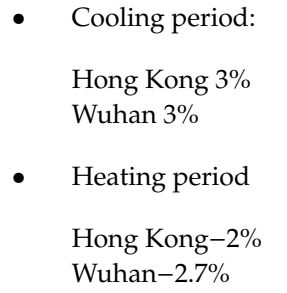 \\
\hline
\end{tabular}


Table 4. Cont.

\begin{tabular}{|c|c|c|c|c|c|c|c|c|}
\hline Ref & Type & Climate & GST & Plant Species & Application & Period & Indoor & Energy Saving \\
\hline [56] & Num. & $\begin{array}{l}\text { Siena } \\
\text { (Csa - Hot-summer } \\
\text { Mediterranean climate) }\end{array}$ & Indirect $L W$ & $\begin{array}{l}\text { Plants embedded in the felt } \\
\text { layers, without substrate, } \\
\text { with mass of } 20 \mathrm{~kg} / \mathrm{m}^{2}\end{array}$ & $\begin{array}{l}\text { One façade south } \\
\text { orientated of a building }\end{array}$ & One year & & $\begin{array}{ll}\text { - } & \text { Cooling period: } \\
& \\
\text { Massive wall }+L W \\
\text { (open air cavity): } \\
15.2 \% \\
\text { Massive wall }+L W \\
\text { (closed air cavity): } \\
14.0 \% \\
\text { Insulated wall }+L W \\
\text { (open air cavity): } 6.7 \% \\
\text { Insulated wall }+L W \\
\text { (open air cavity): } 6.2 \% \\
\\
\text { Heating period: } \\
\text { No variation }\end{array}$ \\
\hline [77] & Exp. & $\begin{array}{l}\text { Puigverd de Lleida } \\
\text { (Csa - Hot-summer } \\
\text { Mediterranean climate) }\end{array}$ & Indirect $G F$ & $\begin{array}{l}\text { Ivy (Hereda helix), } \\
\text { Honeysuckle (Lonicera } \\
\text { japonica), Boston Ivy } \\
\text { (Parthenocissus } \\
\text { Tricuspidata) and Clematis }\end{array}$ & $\begin{array}{l}\text { Half façade south } \\
\text { oriented of a test room }\end{array}$ & $\begin{array}{l}6 \text { days of cooling } \\
\text { period }\end{array}$ & $T_{\text {set-poit }}: 24^{\circ} \mathrm{C}$ & 1\% Daily \\
\hline [78] & Exp. & $\begin{array}{l}\text { La Rochelle } \\
\text { (Cfb - Oceanic climate) }\end{array}$ & Indirect $L W$ & $\begin{array}{l}\text { Six different species on } \\
\text { Chile sphagnum of } 15 \mathrm{~cm}\end{array}$ & $\begin{array}{l}\text { West façade of } \\
\text { test room }\end{array}$ & $\begin{array}{l}\text { August } 2012 \\
\text { December } 2012\end{array}$ & & $\begin{array}{l}\text { - } \quad \text { August: } 67 \% * ; \\
\text { - } \quad \text { December: } 20 \%\end{array}$ \\
\hline [79] & Num. & $\begin{array}{l}\text { Hong Kong } \\
\text { (Cwa - Humid subtropical climate) }\end{array}$ & Indirect $G F$ & $\begin{array}{l}\text { Divided Creeper: } \\
\text { deciduous }\end{array}$ & Whole Building & Cooling period & $T_{\text {set-poit }}: 24^{\circ} \mathrm{C}$ & $76 \%$ \\
\hline [80] & Num. & $\begin{array}{l}\text { Kelowna } \\
\text { (Dfb - Warm-summer humid } \\
\text { continental climate) }\end{array}$ & Direct $L W$ & & $\begin{array}{l}\text { All façades of } \\
\text { a building }\end{array}$ & One year & & $\begin{array}{l}\text { - } \quad \text { Cooling period: } 7.3 \% \\
\text { - Heating period: } \approx 0 \%\end{array}$ \\
\hline [81] & Num. & $\begin{array}{l}\text { Genoa } \\
\text { (Csa - Mediterranean climate) }\end{array}$ & Indirect $G F$ & $\begin{array}{l}20 \text { species both climbing } \\
\text { plants and shrubs. }\end{array}$ & $\begin{array}{l}\text { South façade of an } \\
\text { office building }\end{array}$ & June- September & $T_{\text {set-poit }}: 26^{\circ} \mathrm{C}$ & $26 \%$ \\
\hline [82] & Num. & $\begin{array}{l}\text { Singapore } \\
\text { (Af - Tropical rainforest climate) }\end{array}$ & Indirect $L W$ & Turfing & $\begin{array}{l}\text { Whole building } \\
\text { (Different Windows to } \\
\text { Wall ratio) }\end{array}$ & Cooling period & $T_{\text {set-poit }}: 24{ }^{\circ} \mathrm{C}$ & $\begin{array}{l}\text { Scenarios: } \\
\text { 1A: } 74.29 \% \\
\text { 2B: } 10.35 \% \\
\text { 3C: } 17.93 \%\end{array}$ \\
\hline
\end{tabular}


In the city of La Rochelle (France), characterized by an Oceanic climate, the experiments of GWs revealed positive effects in summer while, concerning the winter season, also moderate reduction of heat losses was verified [78]. The paper [35] allows the comparison between GF and LW in the same conditions (internal and external) also by adopting different plant species. Briefly, for each cooling set-point temperature, the $L W$ under investigation has the best behavior.

Very significant results, in terms of quantifications, are obtained in [79]; really, these outcomes are very optimistic and probably this is because, for this passive technology, the cooling load has been estimated with a simplified steady-state method. In the same vein, also the study proposed in [32] can be only partially used as a reference, because the behavior of a GF is analyzed only for one day of the cooling period; thus, these data are not comparable with experiments for the same climatic conditions, nor with other numerical studies.

As can be seen from these notes, all papers about $L W$ s differ for climatic conditions, type of system and plant species. This implies that comparisons cannot be done.

Finally, it can be also underlined that buildings with vegetated facades can influence (often significantly) the performance of a building without a green system, as shown by Djedjig et al. [54]. They have found that GWs, east and west oriented, installed on a building, reduces by $37 \%$ the cooling load of nearby buildings with an aspect ratio (height to width of the street canyons) equal to one, in Mediterranean summer climate.

Some papers investigate also the effect of GWs during the heating period. More in detail, some authors, with the simulation approach $[56,80]$, have shown that there is no penalty during the winter when the $L W$ is placed on the north side or if it covers all façades. Conversely, the study [52] highlights an increase in heating demand (around 2-3\%), by underlining that the summer performance is however sufficient for compensating this effect in the annual energy balance. Also in this case, it is not possible to give some general conclusions since climate, mathematical model, indoor conditions are really different in the available papers.

Several phenomena have to be taken into account also during the winter period; first of all, the greenery system protects the façade and composes a buffer that is warmer than the exterior temperature causing a higher surface temperature, moreover, it modifies the thermal resistance of the wall, affects the wind convection, but it also reduces the heat gains during the sunny hours. Tudiwer and Korjenic [83] have presented an experimental in-depth analysis about the winter behavior for an oceanic climate, bordering a humid subtropical climate ( $\mathrm{Cfb}$ - Köppen classification). They have explored a method to calculate the resistances of the facades with measured data. More in detail, the additional heat resistance is counted in the surface external resistance. The authors have calculated an increment of the total thermal resistance between $0.31 \mathrm{~m}^{2} \mathrm{~K} / \mathrm{W}$ and $0.68 \mathrm{~m}^{2} \mathrm{~K} / \mathrm{W}$. This result cannot be generalized because it depends on the greening system (plants and ventilation gap) and its location. For this reason, He et al. [22] have defined a formulation for the additional equivalent thermal resistance. By means of a validated model, they have found that it is about $9.16 \mathrm{~m}^{2} \mathrm{~K} / \mathrm{W}$ in summer and $0.97 \mathrm{~m}^{2} \mathrm{~K} / \mathrm{W}$ in winter, so it is not the same value during different seasons. Moreover, Perini et al. [43] have concluded that when the foliage or the other layers reduce the wind speed outside $(<0.2 \mathrm{~m} / \mathrm{s})$, the external surface resistance can be equalized to internal one; thus the thermal resistance of the wall increases of $0.09 \mathrm{~m}^{2} \mathrm{~K} / \mathrm{W}$.

The comparison between experimental and numerical results is difficult to do, considering the available studies. In details, papers based on comparison between monitored and simulated energy savings are not available in the literature. However, only for the Mediterranean climate, looking to results reported in [35] and [56], it seems that the simulation studies underestimate the energy penalty during the winter and also the benefit during the summer.

Considering the aspect of building energy performance, the state of art seems quite incomplete; moreover, it can be underlined that all studies investigate the thermal performances in terms of the energy needs and not the primary energy saving, meanwhile the performance of the whole "building-HVAC system" could be interesting to investigate. This would make it possible to highlight 
the influence on the performance of different types of systems due to the lower internal temperature fluctuations and the reduction of peak values. Moreover, there are no studies about the incidence of energy consumptions for pumps and other irrigation equipment; these could influence, negatively, both the annual energy balance and economic profitability.

\subsubsection{Effects on the Indoor Microclimatic Comfort}

The great part of available studies analyzes the incidence of a $G W$ on indoor comfort in terms of air and surface indoor temperature reduction. Table 5 summarizes the results of selected papers evidencing that only one of these adopts the numerical approach. Really, the correct evaluation of effects on thermo-hygrometric comfort would require also the evaluation of other parameters, and thus time lag, time shift, discomfort hours, relative humidity, indoor airspeed as well as the calculation of predicted mean vote and dissatisfied people percentage. Really, only a few studies calculate some of them, and not uniquely; for this reason, they are not shown in the table. Moreover, according to authors, the effect of vegetated walls in terms of a surface temperature reduction should be evaluated by considering a free-floating regime because the passive effect of a green system is directly evaluated. Oppositely, several papers present the results of monitoring when the HVAC systems run.

The organization of Table 5 is similar to the previous ones. The type of paper is indicated as well as the climate, the type of $G W$, the reference period, the boundary conditions and the monitored data.

The Mediterranean climate is most frequently investigated and also the application of greenery on the south exposure. Direct $L W$ s are most diffused and the characterization period is usually the summer months. Indeed, only two papers analyze also the winter period showing a reduction of air temperature: $0-2{ }^{\circ} \mathrm{C}$ in the Mediterranean climate [84] and $2-3{ }^{\circ} \mathrm{C}$ in tropical climate [16]. Considering the $L W$ in the Mediterranean climate, the reduction of surface temperature seems consistent for the analyzed set-up and comparable among these experiments. For the air temperature, west exposure shows the lowest potentiality. Data for indirect systems are not comparable because these are available for different climates. Instead, by comparing direct $L W$ and indirect GF in Mediterranean climates, the GFs are characterized by the worst performance. The analysis of data for direct GFs suggests that, for air-conditioned buildings, the climates have not particular effect on surface temperature reduction.

A general conclusion is that the reduction of surface temperature reflects the external surface variation, thus the analysis of climatic data can be used for choosing the best orientation of a $G W$. Moreover, by limiting the diurnal fluctuation of wall surface temperatures, the lifespan of building facades is prolonged, slowing down wear and tear as well as savings in maintenance cost and the replacement of some parts. However, the quantification of these aspects in terms of life cycle cost analysis has not been done. Finally, it could be an interesting research field.

\subsubsection{Noise Reduction}

The greenery systems modify also the acoustic performance of a traditional wall. Van Renterghem et al. [84] have shown that the effect of wall vegetation strongly depends on the assumptions of the material parameters. This study is performed with a numerical evaluation of impacts on road traffic noise. Their study has also indicated that the substrates usually used for GST have high porosity and low density and consequently these show complex acoustic behavior. Horoshenkov et al. [85], by means of an experiment in an impedance tube on four different plant species, have concluded that the absorption coefficient of plants is controlled predominantly by the leaf area density and angle of leaf orientation. Hong-Seok et al. [86] have performed several measurements in a reverberation chamber, by showing that also a thin soil layer with a depth of $50 \mathrm{~mm}$ can provide a significant absorption coefficient (about 0.9 at around $1000 \mathrm{~Hz}$ ). A significant decrease was observed with the increase in soil moisture content. Conversely, with the growth of the vegetation coverage, the absorption coefficient increases by about 0.2 at low and mid frequencies. 
Table 5. Results indoor thermal comfort.

\begin{tabular}{|c|c|c|c|c|c|c|c|c|}
\hline \multirow{2}{*}{ Ref. } & \multirow{2}{*}{ Type } & \multirow{2}{*}{ Climate } & \multirow{2}{*}{ GST } & \multirow{2}{*}{ Application } & \multirow{2}{*}{ Period } & \multirow{2}{*}{ Indoor } & \multicolumn{2}{|c|}{ Indoor Temperature Reduction } \\
\hline & & & & & & & Air Temperature & Surface Temperature \\
\hline [16] & Exp. & $\begin{array}{l}\text { Phitsanulok (Aw or As - } \\
\text { Tropical wet and dry or } \\
\text { savanna climate) }\end{array}$ & Indirect $L W$ & $\begin{array}{l}\text { One façade of test-box } \\
\text { south exposed }\end{array}$ & $\begin{array}{l}6 \text { months } \\
\text { - (December-May) }\end{array}$ & NS & $\begin{array}{l}\text { Mean values: } \\
\text { Summer: } \\
\text { Day: } 1.28^{\circ} \mathrm{C} / \\
\text { Night: } 1.16^{\circ} \mathrm{C} \\
\text { Winter } \\
\text { Day: } 2.63^{\circ} \mathrm{C} / \\
\text { Night: } 1.90^{\circ} \mathrm{C}\end{array}$ & $\begin{array}{l}\text { Mean values: } \\
\text { Summer: } \\
\text { Day: } 0.99^{\circ} \mathrm{C} / \\
\text { Night: } 0.65^{\circ} \mathrm{C} \\
\text { Winter } \\
\text { Day: } 2.16^{\circ} \mathrm{C} / \\
\text { Night: } 1.17^{\circ} \mathrm{C}\end{array}$ \\
\hline [18] & Exp. & $\begin{array}{l}\text { Puigverd de Lleida (Csa - } \\
\text { Hot-summer Mediterranean } \\
\text { climate) }\end{array}$ & Indirect $G F$ & All facades of a test room & $\begin{array}{l}\text { Summer } 2013 \\
\text { Summer } 2015\end{array}$ & Free floating & & $\begin{array}{l}\text { Mean daily values: } \\
\text { - 2013: } 2.5^{\circ} \mathrm{C} \text {; } \\
\text { - 2015: } 2.0^{\circ} \mathrm{C} \text {. }\end{array}$ \\
\hline [19] & Exp. & $\begin{array}{l}\text { Chicago (Dfa - Hot-summer } \\
\text { humid continental climate) }\end{array}$ & Direct GF & $\begin{array}{l}\text { Part of building wall South } \\
\text { exposed }\end{array}$ & $\begin{array}{l}3 \text { days of August } \\
1 \text { day of September }\end{array}$ & $\begin{array}{l}\text { Air-conditioned } \\
\text { office }\end{array}$ & & $\begin{array}{l}\text { Mean value: } \\
\text { 29/08: } 1.5^{\circ} \mathrm{C} \\
30 / 08: 0.6^{\circ} \mathrm{C} \\
31 / 08: 0.7^{\circ} \mathrm{C} \\
1 / 09: 0.8^{\circ} \mathrm{C}\end{array}$ \\
\hline [31] & Exp. & $\begin{array}{l}\text { Wuhan (Cfa - Humid } \\
\text { subtropical climate) }\end{array}$ & Indirect $L W$ & $\begin{array}{l}\text { One façade of a test room } \\
\text { West oriented }\end{array}$ & 1 day of July & Free floating & $\begin{array}{l}\text { Mean value: } 4^{\circ} \mathrm{C} \\
\text { Maximum value: } \\
1.1^{\circ} \mathrm{C}\end{array}$ & Maximum value: $7.7^{\circ} \mathrm{C}$ \\
\hline [32] & Num. & $\begin{array}{l}\text { Thessaloniki (Cfa - Humid } \\
\text { Subtropical Climate) }\end{array}$ & Direct $G F$ & All façades of a test room & Cooling period & $\begin{array}{l}\text { Cooling period } \\
T_{\text {set-poit: }} 20^{\circ} \mathrm{C} \\
\text { (Schedule } \\
\text { 8:00-20:00) } \\
\text { Infiltrations: } 1 \text { Ach }\end{array}$ & & $\begin{array}{l}\text { Maximum values: } \\
\text { North: } 0.65^{\circ} \mathrm{C} \\
\text { East: } 2.04{ }^{\circ} \mathrm{C} \\
\text { South: } 1.06^{\circ} \mathrm{C} \\
\text { Weast: } 3.27^{\circ} \mathrm{C}\end{array}$ \\
\hline [33] & Exp. & $\begin{array}{l}\text { Covilhã (Csb - } \\
\text { Warm-summer } \\
\text { Mediterranean climate) }\end{array}$ & Direct $L W$ & One façade south oriented & $\begin{array}{l}\text { - } \quad \text { 7-20 October } \\
\text { - } 26 \text { November-9 December }\end{array}$ & $T_{\text {set-poit }}: 20^{\circ} \mathrm{C}$ & & $\begin{array}{l}\text { Maximum values: } \\
\text { Oct: } 4.8^{\circ} \mathrm{C} ; \text { Nov: } 5.9^{\circ} \mathrm{C} \text {. }\end{array}$ \\
\hline [38] & Exp. & $\begin{array}{l}\text { Chicago (Dfa - Hot-summer } \\
\text { humid continental climate) }\end{array}$ & Direct $G F$ & All facades of a building & 6 days of July & $\begin{array}{l}\text { Air-conditioned } \\
\text { office }\end{array}$ & & $\begin{array}{l}\text { Mean values: } \\
\text { East: } 0.3^{\circ} \mathrm{C} \\
\text { South: } 0.5^{\circ} \mathrm{C} \\
\text { West: } 0^{\circ} \mathrm{C} \\
\text { North: } 0.3^{\circ} \mathrm{C}\end{array}$ \\
\hline [44] & Exp. & $\begin{array}{l}\text { Thessaloniki (Cfa - Humid } \\
\text { Subtropical Climate) }\end{array}$ & Direct GF & $\begin{array}{l}\text { One façade of a flat of East } \\
\text { oriented }\end{array}$ & One month (July-August) & NS & & $\begin{array}{l}\text { Maximum value: } \\
0.4-1.6^{\circ} \mathrm{C} \\
\text { Mean value: } 0.9^{\circ} \mathrm{C}\end{array}$ \\
\hline [46] & Exp. & $\begin{array}{l}\text { Colmenar Viejo (Csa - } \\
\text { Hot-summer } \\
\text { Mediterranean climate) }\end{array}$ & Direct $L W$ & One facade South-oriented & 2 months (July-august) & Free floating & Mean value: $4.1^{\circ} \mathrm{C}$ & Mean value: $6.4^{\circ} \mathrm{C}$ \\
\hline
\end{tabular}


Table 5. Cont.

\begin{tabular}{|c|c|c|c|c|c|c|c|c|}
\hline \multirow{2}{*}{ Ref. } & \multirow{2}{*}{ Type } & \multirow{2}{*}{ Climate } & \multirow{2}{*}{ GST } & \multirow{2}{*}{ Application } & \multirow{2}{*}{ Period } & \multirow{2}{*}{ Indoor } & \multicolumn{2}{|c|}{ Indoor Temperature Reduction } \\
\hline & & & & & & & Air Temperature & Surface Temperature \\
\hline [47] & Exp. & $\begin{array}{l}\text { Al-Ain City (BWh - Hot } \\
\text { desert climates) }\end{array}$ & Direct $L W$ & One façade east oriented & 1 month (July) & Free floating & $\begin{array}{l}\text { Day: } 4-6^{\circ} \mathrm{C} \\
\text { Night: } 1-2.5^{\circ} \mathrm{C}\end{array}$ & $\begin{array}{l}\text { Day: } 4.5-6.5^{\circ} \mathrm{C} \\
\text { Night: } 1.5-5^{\circ} \mathrm{C}\end{array}$ \\
\hline [48] & Exp. & $\begin{array}{l}\text { Mawson Lakes (Csb - } \\
\text { Warm-summer } \\
\text { Mediterranean climate) }\end{array}$ & Direct $L W$ & $\begin{array}{l}\text { Part of a building façade } \\
\text { West oriented }\end{array}$ & 8 mounts (December-July) & Free floating & \begin{tabular}{lr}
\multicolumn{2}{l}{ Maximum daily valu } \\
- & Warm days: 1.7 \\
- & Cold days: 0.75
\end{tabular} & \\
\hline [55] & Exp. & $\begin{array}{l}\text { Colmenar Viejo (Csa - } \\
\text { Hot-summer } \\
\text { Mediterranean climate) }\end{array}$ & Direct $L W$ & $\begin{array}{l}\text { One facade of a test room } \\
\text { South-oriented }\end{array}$ & 3 years (2009-2011) & NS & $\begin{array}{l}\text { Mean values: } \\
\text { Winter: } 0-2^{\circ} \mathrm{C} \\
\text { Summer: } 2-7^{\circ} \mathrm{C} \\
\text { Spring: } \approx 2-7^{\circ} \mathrm{C} \\
\text { Autumn } \approx 2-7^{\circ} \mathrm{C}\end{array}$ & $\begin{array}{l}\text { Mean values: } \\
\text { Summer: } 1-11^{\circ} \mathrm{C} \\
\text { Spring: } 5-12{ }^{\circ} \mathrm{C} \\
\text { Autumn } 5-12{ }^{\circ} \mathrm{C}\end{array}$ \\
\hline [77] & Exp. & $\begin{array}{l}\text { Puigverd de Lleida (Csa - } \\
\text { Hot-summer } \\
\text { Mediterranean climate) }\end{array}$ & Indirect $G F$ & $\begin{array}{l}\text { One façade of a test room } \\
\text { South oriented }\end{array}$ & 6 days of September & Free floating & $1^{\circ} \mathrm{C}$ & $0.5-2{ }^{\circ} \mathrm{C}$ \\
\hline
\end{tabular}


Jang et al. [87], with a scale model of a street canyon, have shown that the noise reduction is less than $2 \mathrm{~dB}$, at pedestrian level. Wong et al. [88] have carried out an experimental campaign on eight greenery systems placed in Singapore. Some of the investigated systems have shown a good noise reduction $(5-10 \mathrm{~dB})$ for low to middle-frequency range, due to the absorbing effect of substrate, some others an insertion loss ranging from $2 \mathrm{~dB}$ to $3.9 \mathrm{~dB}$. A smaller attenuation has been observed at high-frequency spectrum due to scattering from greenery. Thus, the authors have concluded that also by considering the high costs of installation and maintenance, vertical greenery systems should not be chosen only for acoustics interventions. Lacasta et al. [42] have measured the absorption coefficients of a modular greenery wall with Helichrysum thianschanicum species and they have found that it is approximately 0.7 . Then, by means of numerical evaluations, they have found a maximum value of 4 $\mathrm{dBA}$ as a noise reduction index for realistic situations. These results do not agree with the conclusions of Azkorra et al. [89]. Indeed, these authors have found, with laboratory measurements, a weighted sound reduction index equals to $15 \mathrm{~dB}$ and a sound absorption coefficient of 0.40 . This difference can be attributed to the level of development of vegetation.

Fernández-Bregón et al. [90] have studied the effects of vertical greenery on sound mitigation for an indoor installation on a concrete wall fully covered with a combination of 16 species of plants that have determined an average canopy height of $250 \mathrm{~mm}$. They have found that, for noise longer than $1 \mathrm{~s}$, the sound reduction mitigation varies between $6 \%$ to $8 \%$ for the selected frequency.

In conclusion, all results demonstrate the GW capacity of reducing noise pollution, but, as underlined by Perez et al. [91], some improvements must be applied in the selection of materials to increase the potentialities in the sound insulation mainly with reference to the traffic noise.

\subsection{Sustainability}

The sustainability of a green vertical system has to be investigated more accurately; indeed, the results of the available papers lead to discordant conclusions. The studies $[92,93]$ have pointed out some aspects that should be considered significant for evaluating the sustainability of GST in a technical standard. They have defined 40 environmental requirements to be taken into account for the whole building process, following the CEN/TC 350 - "Environmental sustainability of construction works". On the base of the studies analyzed in this paper the main environmental requirements for GST have been identified by authors and shown in Table 6.

The sustainability of green systems' design has been discussed by Feng and Hewage [94], which have compared the lifecycle assessment of three LWs in the Netherlands: trellis system, planter box system, and felt layer system. The last one resulted in the worst in terms of environmental sustainability since it needs as many as 23 years to balance the emissions, but its lifetime is about 10 years. Moreover, some general indications have been given: first of all, the materials have to be provided closer to the construction site and with a large percentage of recycled or reused ones; secondly, the vegetation should require little fertilizer and low replacement. Instead, considering the main element of a greening system (bare wall, support system and vegetation), Manso et al. [95] have found that the support has a major impact mainly in terms of Global Warming Potential, representing $96 \%$ of the total environmental burden of this category.

Table 6. Main environmental requirements for GST.

\section{ENVIRONMENTAL REQUIREMENTS FOR GST} MANUFACTURING

\footnotetext{
- Minimizing the thicknesses and weights of the materials that make up the building element

- Maximizing the use of materials produced with low environmental impact techniques

- Maximizing the use of recycled materials

- Maximizing the use of natural materials

- Maximizing the use of materials locally produced

- Maximizing the use of materials with similar lifetime
} 
Table 6. Cont.

ENVIRONMENTAL REQUIREMENTS FOR GST MANUFACTURING

- Maximizing the use of products which can bring benefits in different fields

- Maximizing the use of reused structures coming from partial or total building demolition

\section{ON-SITE INSTALLATION}

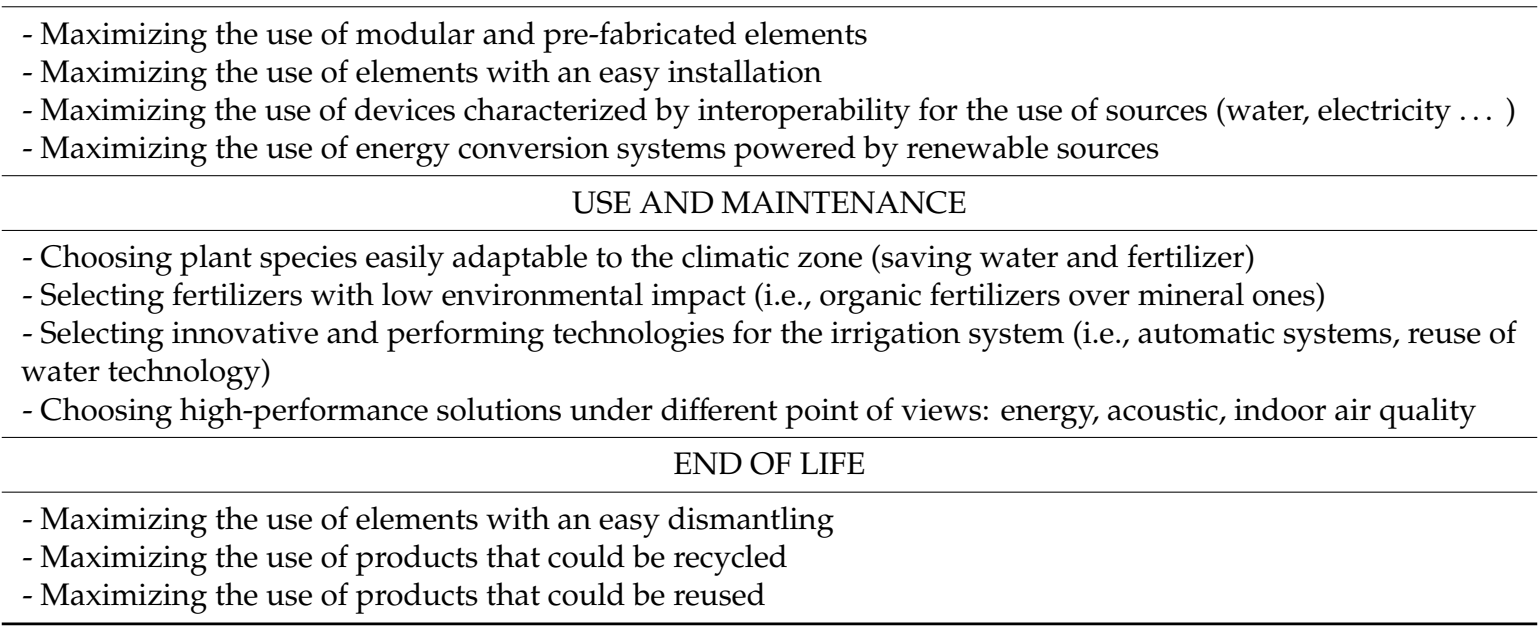

To be sustainable, a product for the building sector must be also economically profitable. For evaluating the economic impact of GST, Perini and Rosasco [96] have carried out a "cost-benefit analysis" of different GWs placed in Mediterranean climates, by taking into account costs and benefits for people (real estate, savings for heating and air conditioning, cladding longevity, and tax incentives) and society (air quality improvement, carbon reduction, habitat creation, aesthetic impact, urban heat island mitigation and tax incentives). The authors have concluded that the most economically sustainable system is the direct green façade. The same authors [97], by considering eight different scenarios in terms of life span (25 and 50 years), economic incentives and disposal at the end of the life span, have found that in the Mediterranean climate, the economic sustainability is obtained only if there is a tax reduction. One of the best scenarios brings to a net present value of $202.93 € / \mathrm{m}^{2}$ for a lifespan of 50 years, by considering tax reduction, reduction of exercise costs due to cooling saving, the increment of building rent and biomass production. Comparable results have been achieved by Ottele et al. [49]; in particular, these authors have shown that $L W$ with felt has a high environmental burden while the ones based on planter boxes have not a major footprint since the materials affect positively the thermal resistance of the system. The relevant impact of the felt-based $L W$ systems on the life cycle assessment has been also shown by Oquendo-Di Cosola et al. [98]. The study found that in the manufacturing, construction and maintenance stage, the LWs with felt have a higher impact than the LWs plastic-based.

In the last decades, a new environmental assessment method, called 'eMergy evaluation', has been adopted; it takes into account some complementary information that allow evaluating the design sustainability, by considering both 'environmental costs' and 'benefits'. With this method, Pulselli et al. [56] have obtained that, for a $L W$ and a $G W$ installed on a massive envelope, 'benefits' do not compensate 'costs' within a reasonable lifespan since the Cost to Benefit Ratio (CBR) is $C B R_{47}=1$ for $L W$ and $C B R_{151}=1$ for GW. These values have been calculated as "the initial emergy investment" (without renewables and human work) to the "the yearly energy benefit" ratio. This result is mainly due to the need for water supply. Thus, rainwater harvesting systems can be useful.

Probably, the most critical aspect for the sustainability of a GST is the water consumption; the results proposed by Perez Urrestarazu et al. [99] have only indicated that the amount of needed water depends on the type of substrate used and the emitter flow rate. Briefly, the issue of irrigation 
and the incidence on the economic profitability is not completely investigated. The design can become truly sustainable only if designers and industry will develop the systems not only in terms of materials but also considering the rainwater storage tanks and water content sensors [6].

Other problems could be related to the maintenance of a GW. Manso et al. [2] in fact, underlined that, in case of the necessary replacement of some plants, it is difficult to restore the continuity of the green surface and for climbing plants, it is complex to ensure the absence of gaps in the facade for the spontaneous growth of the vegetation.

The choice of plants, suitable for the climate conditions, affects the maintenance cost of the green systems. Mårtensson et al. [50], for a $L W$ in cold climates, indeed, underline that it is essential to select evergreen plants that easily adapt to excessive or poor irrigation and to frigid temperatures.

Obviously, the water consumption, the maintenance, the design complexity, the materials involved affect the cost of a green system: a direct or indirect green system is cheaper than a $L W$ system [100].

In conclusion, the available literature suggests that, considering the environmental and economical sustainability, GWs are better than $L W$ s. Taking more into account the social benefits of vertical greening systems, the governments should incentive their installations (for new and existing buildings) and surely the economic sustainability of such systems could be significantly increased. However, professionals and researchers should give more importance to the study of water usage because it influences the optimal performance of a green system but also the economic sustainability of the system.

\section{Remarks from the Review Process}

Different programs, action plans, guidelines have been applied to diffuse this technology and, for this reason, each researcher and designer applies different performance evaluation criteria: thus, the results are often incomparable. However, some general conclusions can be found also by evidencing the main topics that the future research should investigate.

The plant species have a significant impact on the green system behavior. The key aspects for their selection are the natural supporting mechanism, the adaptability to the type of outdoor environment not only in terms of climate conditions, the pest problem, the need for maintenance and irrigation. These aspects are really interrelated, because, for instance, if the species are well adapted to the environment, they require lower maintenance. This implies a reduced amount of water for irrigation, fewer fertilizers and poisons for pest. A proper selection of the plants is really important, because some types cannot survive with a poor maintenance. In any case, periodic inspections have to be done for verifying the health of the plants and their pruning. A green façade has a better behavior than a $L W$ under this point of view. Moreover, the environmental adaptability includes the resistance to drought and winter injury - that can cause wilting and leaf firing - as well as the traffic tolerance. For very height buildings, wind can create significant problems for what concerns the plant attachment. Foliage may be stripped under extreme wind conditions, so foliage type and size should be matched to the level of exposure and likely wind strengths at the site.

The heat exchange is greatly influenced by the plant species selection; it has to be based on climatic zone, also by considering the effects of wind and light exposure, the installation in a hardiness zone or amenity context and the consideration of realistic growth time for plants. Each plant requires an adequate choice of substrate and irrigation method that has to take into account the short and long term maintenances to secure the health (sufficient watering and the regular trimming); this aspect has a great incidence on the exercise costs of the system.

Considering the available literature, it is clear that experimental and numerical studies are realized, very often, without considering the presence of inner loads but these influence greatly the whole heat transfer process; for this reason, the available result can be considered only partially representative of the $G W$ behavior. Moreover, it has to be considered that the effect on thermo-hygrometric comfort should be evaluated by considering free-floating temperature regime, while often the HVAC system is turned on during the monitoring activities. In addition, the evaluation of energy saving is often proposed for very short periods, while the behavior along all seasons should be monitored for evaluating the 
whole, seasonal and annual, energy balance. Indeed, for some passive technologies, it happens that the benefits during the summer period are negatively compensated by highest energy requirements during the winter months. Studies could be carried out to evaluate how the annual budget changes, and therefore the energy saving according to the type of plant, whether it is deciduous or evergreen. About the influence on the building performance, the only possible conclusions are:

- the energy savings provided by GWs depend from the orientation;

- the LWs seem to have better performance than GFs and their design is more difficult;

- the temperature in the interior surface of the vegetal façade is significantly more stable than the temperature in the interior surface of the façade without vegetation, but the calculation of thermal lag seems to demonstrate that GF and $L W$ systems do not provide any significant variation of the thermal inertia of the construction system.

Despite some evident benefits, there are contrasting opinions, among researchers, about the sustainability of GWs. Nevertheless, these systems contribute directly to achieving credits in the application of green rating systems but, considering a complete life cycle analysis, the whole impact is not always suitable. Moreover, it seems necessary to perform appropriate studies about the evaluation of irrigation rate; indeed, it influences the evapotranspiration process and thus the efficiency of the whole system as well as the maintenance costs and the economic profitability of the technology.

The review analysis allows also to evidence that the scientific results are mainly focused on the monitoring of green vertical systems, without explaining the consideration about the selected plants and the influence of the kind of back wall. Indeed, there are not many numerical studies and, really, some parametric evaluations could be very useful for choosing the optimal configuration of a green system by varying climate conditions, building kind of use and type of material or technological solution coupled with green layers. For instance, it could be interesting the evaluation of the adoption of recycled materials for the substrate or the integration of phase change material on the back whole. Moreover, the technical parameters that characterize each sub-system should be detailed in appropriate guidelines both in terms of:

- performance requirements,

- proposition of suitable catalogues for designers.

It can be also remarked that some numerical tools have been proposed and used for performance estimations, but a complete characterization has not been proposed, e.g., the description of boundary conditions for the heat and moisture balances is quite always inadequate and incomplete, and thus the model cannot be used by other researchers. Moreover, there are no studies that accurately perform computational fluid dynamic (CFD) investigations and, analogously, there is a lack of monitored data, that allow the evaluation of the thermal field of each substrate as well as the incidence of vapor diffusion phenomena.

The proposed analysis allows to evidence that the design, installation and maintenance of a GW regard several multidisciplinary aspects (structural, energetic, economic and so on) that have to be taken into account simultaneously by designers or decision-makers for optimizing the behavior of system and also for minimizing related costs. Indeed, $G F$ and $L W$ could require different evaluations that do not concern merely the thermal, energy or comfort fields. For instance, Sheweka and Magdy [101] have remarked the importance of satisfying the structural requirements; indeed the anchorage system to the building envelope has to be studied, as well as the calculations of loads due to substrate, plants and all elements included the non-constant ones like wind, rain or accumulated snow. It is also really important to verify the competencies of installers so that the project can be successfully completed.

Considering all the discussed aspects, it seems advisable the adoption of a multi-criteria decision-making approach for vertical $G W$ design. With the aim to help designers and researchers in the evaluation of impact of the main elements of a vertical green system (i.e., layout, vegetation, substrate, supporting element, irrigation and drainage), it is proposed a matrix of strengths, weaknesses, 
opportunities, and threats (SWOT) that could be intended as a starting point to select the criteria and evaluation indexes when the design is approached.

The strengths of envelope solutions might include their ability to improve the whole building performance or to impact on the environmental issues related to energy use in building. Factors that can be considered as part of an analysis of strengths include:

- the advantages that these solutions can provide;

- $\quad$ what the solution does better than other technologies;

- $\quad$ the market penetration;

- $\quad$ the quantity of saved not-renewable energy sources.

Figure 2 shows the proposed matrix for the green vertical systems, according to all aspects evidenced in the review analysis. The weaknesses include designers or installation teams that do not have specific knowledge and experiences, unreliable technical data of each sub-system (which aspects can be improved by the scientific research).

Some threats can be external, such as a slow-down in the building sector, absence or negative changes of normative approach. Other threats may be internal, such as a poor knowledge or available technical tools. Factors that can be considered as part of an analysis of threats include potential obstacles due to high costs or negative impacts of life cycle sustainability. Indeed, a green system can add a big value to the development of the building sector, with creation of accessible, secure and healthy built environments, but it should respect some constraints during the life cycle to be a sustainable solution. This means that the design must assure low impacts in terms of energy, water and raw materials.

Finally, by considering the threats, it can be underlined that, in order to improve the features of products and the design, a key role may be played by definition of international technical standards. These can also contribute to avoid criticalities due to not appropriate designing, unsustainable or inadequate irrigation rate, structural problems, infiltrations of water, and so on.

Several strengths and opportunities have to be taken into account by designers and researchers, in order to accelerate the process of dissemination of this technology. More in detail, benefits in terms of reduction of energy needs for building air-conditioning and improvements of the global indoor and outdoor comfort have to be quantified. As previously cited, it could be difficult to compare the results of the different studies, because every researcher has adopted different evaluation criteria. In the case of the energy-saving, the orientation, the climatic zone, the typology of vegetation, the $L A I$, but also the stratigraphy of the wall, could have a key role in its determination. As reported in Table 3, the typology of green system, and thus a direct or indirect GF and a direct or indirect $L W$, can have a different impact on the energy demand of the building. For what concerns the UHI mitigation, some general conclusions can be underlined:

- at the same conditions, a $L W$ assures the highest reduction of temperature in the warm-summer Mediterranean climate and humid subtropical climate, with better results on the southern façade.

- evergreen plants and the increment of $L A I$ have positive effects on the reduction of the surface temperature.

- $\quad$ for GF, the temperature reduction is highest when the foliage is more intensive, thicker and closer to the ground [28].

The reduction of the internal surface temperature and thus the improvement of the summer indoor comfort is strongly related to the reduction of the external surface temperature. Moreover, the limitation of the diurnal fluctuation of wall surface temperatures could prolong the lifespan of building facades, by slowing down wear and tear. Moreover, the is also the opportunity of savings in maintenance costs and the replacement of some parts. Other strengths points of a green system are the air pollution control, depending on the plant species, and the stormwater management even if not evidenced by experimental studies. Furthermore, the reduction of traffic noise in an urban context has been proved by numerical and experimental studies and it could be improved by a meticulous selection of the $G W$ 
materials. Opportunities can arise from expanding the building market, improving other aspects at the social level, using the expertise of a particular sector to anticipate where the market will go next. A $G W$ is an opportunity also for the preservation of biodiversity, without compromising the social utilization of the urban space. Figure 4 shows some photo insertions made by the authors of green walls integrated in a cemented urban context or in a backcountry place.

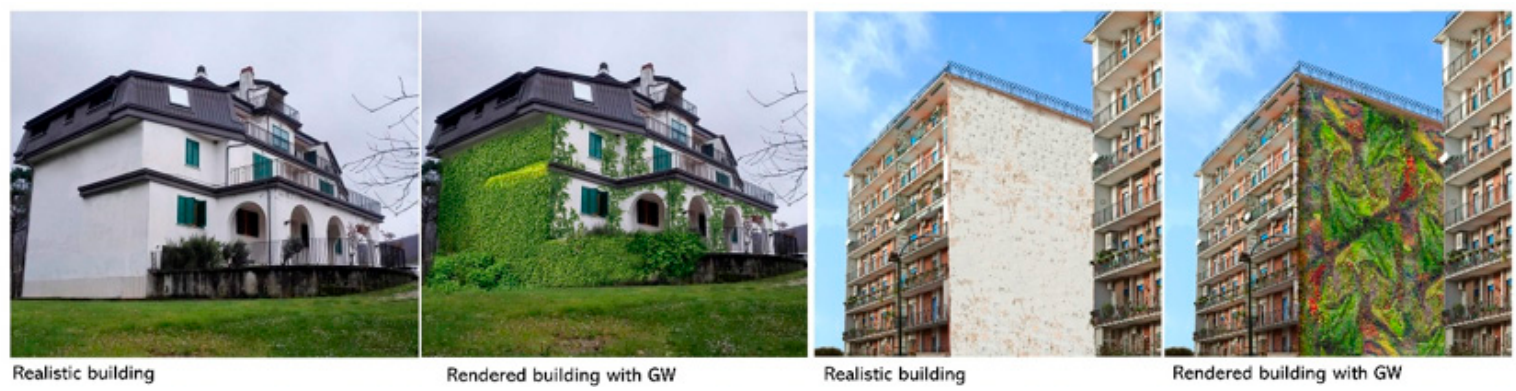

Figure 4. Examples of applications of GW, spontaneously or in façade retrofit.

With reference to the SWOT matrix, the main shown opportunities and the strengths are the advantages widely demonstrated by researchers and these will acquire greater importance by considering the increase in global temperature and the growing need to redevelop urban centers. It is obvious that, by increasing the number of green walls or roof integration in densely urbanized areas, the phenomena of noise reduction, improvement of indoor and outdoor comfort, the contribution to urban biodiversity, the limitation of air pollution will become more and more relevant. The negative aspects evidenced in Figure 5, summarized in weakness and threats, could be partially limited in the future. For example, the inexperience of designers or the lack of technical data could be filled by intensive technical preparation and in the same way, the environmental impact or the weight of material could be solved by greater attention during the design and selection of materials. Certainly, some of these aspects could be improved with future public regulations and normative standards. The cited points in the figure below should be intended as examples, and thus these are indicative and not exhaustive.

\section{LIVING WALLS AND GREEN FACADES: SWOT MATRIX}

\begin{tabular}{|c|c|c|}
\hline & HELPFUL TO ACHIEVING THE OBJECTIVE & HARMFUL TO ACHIEVING THE OBJECTIVE \\
\hline & STRENGTHS & WEAKNESSES \\
\hline 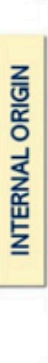 & $\begin{array}{l}\text { - ENERGY SAVING related to climate conditions, } \\
\text { LAI, species, orientation, see table } 4 \text {. } \\
\text { - INDOOR COMFORT: possible improvement shown } \\
\text { in table } 5 \text {. } \\
\text { - UHIMITIGATION: positive effects at the urban } \\
\text { scale, see table } 3 \text {. } \\
\text { - AIR POLLUTION CONTROL: filtering of particulates. } \\
\text { - STORM-WATER MANAGEMENT: mitigation of the } \\
\text { peak of sewage system. } \\
\text { - NOISE REDUCTION: reduction of sound levels in } \\
\text { buildings. }\end{array}$ & $\begin{array}{l}\text { WATER REQUIREMENT. Quantity depends on } \\
\text { several factors, e.g. substrate and plant species. } \\
\text { MAINTENANCE COSTS. Periodic replacement of } \\
\text { plants and other cares have to be considered. } \\
\text { - LACK OF TECHNICAL DATA. No common design } \\
\text { standards are available. } \\
\text { - DESIGNERS UNTRAINED. There is the need of } \\
\text { specialized designers and construction workers. } \\
\text { - SUSCEPTIBILITY TO AVERSITIES: Possible risks } \\
\text { are the behavior against fire, and the attack of } \\
\text { Fungi and Insects. }\end{array}$ \\
\hline & OPPORT & THREATS \\
\hline 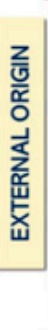 & $\begin{array}{l}\text { - LONGER LIFESPAN OF FACADES. The green can } \\
\text { protect the buildings. } \\
\text { - CONTRIBUTE TO URBAN BIODIVERSITY. } \\
\text { Opportunity of vegetation in cities. } \\
\text { - INCREMENT OF PROPERTY VALUE. Requalification } \\
\text { or added quality of constructions. } \\
\text { - GOOD ESTHETIC APPEARANCE. Architectonic } \\
\text { value, for both new and existing buildings. } \\
\text { - DIVERSIFICATION OF BUILDING MARKET. A new } \\
\text { facade solution that can be the novelty. }\end{array}$ & $\begin{array}{l}\text { - LIFE CYCLE ASSESSMENT. Feasibility has to be } \\
\text { evaluated along the lifespan. } \\
\text { - ENVIRONMENTAL IMPACT. Watering and } \\
\text { suitability for the climate need evaluations. } \\
\text { - LIFE CYCLE COSTS. Maintenance and artificial } \\
\text { irrigation along the life. } \\
\text { - WEIGHT OF MATERIALS. Verification of the back } \\
\text { wall and the anchor systems. } \\
\text { - LACK OF TECHNICAL TOOLS. No consolidated } \\
\text { simulation tools are available. }\end{array}$ \\
\hline
\end{tabular}

Figure 5. SWOT matrix for green vertical systems. 


\section{Conclusions}

GWs have a great potential for improving the building energy performance, the acoustic and the indoor microclimatic comfort. Moreover, several positive effects are achieved at the urban scale, and thus positive environmental changes in dense urban areas.

Here, a large review study is proposed, allowing to conclude that, although the researches in the field of vertical greening is already fairly well advanced, this technology is not yet adequately diffused in consideration of the large potentialities.

In matter of scientific researches, the available papers propose information on system functionality and achievable benefits, often without specifying designing methodology or technical data, and thus designers are not completely allowed to characterize all subsystems.

This review illustrates examples of research gaps such as the lack of consistency in data collection methods, caused, probably, by the absence of an international standard in matter of vertical greening systems. Other criticalities regard the incomparability of experimental and numerical results in terms of energy saving and thermal comport. Often, results reflect only partially the behavior under real conditions (inner loads are usually not considered) and there are not parametric evaluations for the same configurations in different climatic conditions. Moreover, it is difficult to understand the sustainability level during the life cycle and also it is often impossible the quantification of the incidence of irrigation costs on economic profitability.

With reference to all these points, the proposed review offers also some ideas on future approaches and complementary studies, for instance with reference to the need of sensitivity analysis by varying the back wall type and the climatic conditions, cost-benefits studies and so on.

These studies should be done with a multidisciplinary approach. Indeed, the proposed SWOT Matrix has been developed to reveal the drivers and barriers in the course of implementing GWs. Finally, in our investigation, we also attempt to explore the internal and external conditions, which can contribute to the customization and prioritization of policy recommendations for the adoption of international standards.

Author Contributions: S.R. proposed and prepared the initial investigation (Conceptualization and Writing). M.M. then provided a further deepening (Data Curation and Formal analysis). Materials and methodologies were supervised by R.F.D.M. and F.A. (Methodology and Data Curation). The overall balance and scientific relevance were finally defined by G.P.V. (Supervision, review \& editing). The contributes are evaluated as equal. All authors have read and agreed to the published version of the manuscript.

Funding: This research was funded by Horizon 2020, grant number 723825, for the project titled Green INSTRUCT - Green INtegrated STRUCTural elements for retrofitting and new construction of buildings

Conflicts of Interest: The authors certify that they have NO affiliations with or involvement in any organization or entity with any financial interest (such as honoraria; educational grants; participation in speakers' bureaus; membership, employment, consultancies, stock ownership, or other equity interest; and expert testimony or patent-licensing arrangements), or non-financial interest (such as personal or professional relationships, affiliations, knowledge or beliefs) in the subject matter or materials discussed in this manuscript.

\section{Nomenclature}

$\begin{array}{llll}\text { CBR } & \text { cost to benefit ratio }[-] \text { or }[\mathrm{se} / \mathrm{se}] & S L A & \text { specific leaf area }\left[\mathrm{m}^{2} / \mathrm{kg}\right] \\ \text { COD } & \text { chemical oxygen demand }[\mathrm{mg} / \mathrm{L}] & T N & \text { total nitrogen }[\mathrm{mg} / \mathrm{L}-\mathrm{N}] \\ \text { CFD } & \text { computational fluid dynamic } & T P & \text { total phosphorus }[\mathrm{mg} / \mathrm{L}-\mathrm{P}] \\ \mathrm{C}_{\mathrm{p}} & \text { specific heat }[\mathrm{J} / \mathrm{kg} \mathrm{K}] & T_{\text {set-poit }}: & \text { set-point temperature }\left[{ }^{\circ} \mathrm{C}\right] \\ \text { E. coli } & \text { escherichia coli }[\mathrm{MPN} / 100 \mathrm{~mL}] & T S S \quad \text { total suspended solids }[\mathrm{mg} / \mathrm{L}] \\ \text { Exp } & \text { experimental study } & U & \text { thermal transmittance value }\left[\mathrm{W} / \mathrm{m}^{2} \mathrm{~K}\right] \\ G F & \text { green façade } & U H I \quad \text { urban heat island } \\ \text { GST } & \text { green vertical system } & U V \text { ultraviolet } \\ G W & \text { green wall } & \text { WTP willingness to pay }[-] \\ H I & \text { heat index }\left[{ }^{\circ} \mathrm{C}\right] & \text { Greek letters } \\ H V A C & \text { heating ventilation and air conditioning } & \alpha_{l} \text { absorption coefficient of the leaf }[-]\end{array}$


$k \quad$ radiation attenuation coefficient [-] $\quad \alpha_{S}$

LAI leaf area index [-] or $\left[\mathrm{m}^{2} / \mathrm{m}^{2}\right]$

LW living wall

Num numerical study

$r_{l} \quad$ stomatal resistance [s/m]

SWOT strengths weaknesses opportunities threats $\rho$ absorption coefficient of the soil [-]

emissivity of the leaf [-]

emissivity of the soil [-]

thermal conductivity $[\mathrm{W} / \mathrm{m} \mathrm{K}]$

density $\left[\mathrm{kg} / \mathrm{m}^{3}\right]$

\section{References}

1. Newton, J.; Gedge, D.; Early, P.; Wilson, S. BUILDING GREENer-Guidance on the Use of Green Roofs, Green Walls and Complementary Features on Buildings; CIRIA Press: London, UK, 2007.

2. Manso, M.; Castro-Gomes, J. Green wall systems: A review of their characteristics. Renew. Sustain. Energy Rev. 2015, 41, 863-871. [CrossRef]

3. Rakhshandehroo, M.; Yusof, M.; Johari, M.; Deghati Najd, M. Green Façade (Vertical Greening): Benefits and Threats. Appl. Mech. Mater. 2015, 747, 12-15. [CrossRef]

4. Susorova, I. Green facades and living walls: vertical vegetation as a construction material to reduce building cooling loads. In Eco-Efficient Materials for Mitigating Building Cooling Needs; Woodhead Publishing: Cambridge, UK, 2015; pp. 127-153.

5. Pérez, G.; Rincón, L.; Vila, A.; González, J.M.; Cabeza, L.F. Green vertical systems for buildings as passive systems for energy savings. Appl. Energy 2011, 88, 4854-4859. [CrossRef]

6. Riley, B. The state of the art of living walls: Lessons learned. Build. Environ. 2017, 114, 219-232. [CrossRef]

7. Medl, A.; Stangl, R.; Florineth, F. Vertical greening systems-A review on recent technologies and research advancement. Build. Environ. 2017, 125, 227-239. [CrossRef]

8. Pérez, G.; Coma, J.; Martorell, I.; Cabeza, L.F. Vertical Greenery Systems (VGS) for energy saving in buildings: A review. Renew. Sustain. Energy Rev. 2014, 39, 139-165. [CrossRef]

9. Safikhani, T.; Abdullah, A.M.; Ossen, D.R.; Baharvand, M. A review of energy characteristic of vertical greenery systems. Renew. Sustain. Energy Rev. 2014, 40, 450-462. [CrossRef]

10. Hunter, A.M.; Williams, N.S.G.; Rayner, J.P.; Aye, L.; Hes, D.; Livesley, S.J. Quantifying the thermal performance of green facades: A critical review. Ecol. Eng. 2014, 63, 102-113. [CrossRef]

11. Besir, A.B.; Cuce, E. Green roofs and facades: A comprehensive review. Renew. Sustain. Energy Rev. 2018, 82, 915-939. [CrossRef]

12. Charoenkit, S.; Yiemwattana, S. Living walls and their contribution to improved thermal comfort and carbon emission reduction: A review. Build. Environ. 2016, 105, 82-94. [CrossRef]

13. Susorova, I.; Bahrami, P. Facade-Integrated Vegetation as an Environmental Sustainable Solution for Energy-Efficient Buildings; MADE Research Journal of Cardiff University: Cardiff, UK, 2013; pp. 6-14.

14. Watson, D.J. Comparative physiological studies in the growth of field crops. I. Variation in net assimilation rate and leaf area between species and varieties, and within and between years. Ann. Bot. 1947, 11, 41-76. [CrossRef]

15. Breda, N.J. Ground-based measurements of leaf area index: A review of methods, instruments and current controversies. J. Exp. Bot. 2003, 54, 2403-2417. [CrossRef] [PubMed]

16. Charoenkit, S.; Yiemwattana, S. Role of specific plant characteristics on thermal and carbon sequestration properties of living walls in tropical climate. Build. Environ. 2017, 115, 67-79. [CrossRef]

17. Koyama, T.; Yoshinaga, M.; Hayashi, H.; Maeda, K.; Yamauchi, A. Identification of key plant traits contributing to the cooling effects of green façades using freestanding walls. Build. Environ. 2013, 66, 96-103. [CrossRef]

18. Pérez, G.; Coma, J.; Sol, S.; Cabeza, L.F. Green facade for energy savings in buildings: The influence of leaf area index and facade orientation on the shadow effect. Appl. Energy 2017, 187, 424-437. [CrossRef]

19. Susorova, I.; Angulo, M.; Bahrami, P.; Stephens, B. A model of vegetated exterior facades for evaluation of wall thermal performance. Build. Environ. 2013, 67, 1-13. [CrossRef]

20. The Guide to Hydrological Practices (WMO, No. 168). 2008. Available online: http://www.whycos.org/hwrp/ guide/index.php (accessed on 18 April 2020).

21. Libessart, L.; Kenai, M.A. Measuring thermal conductivity of green-walls components in controlled conditions. J. Build. Eng. 2018, 19, 258-265. [CrossRef] 
22. He, Y.; Yu, H.; Ozaki, A.; Dong, N.; Zheng, S. An investigation on the thermal and energy performance of living wall system in Shanghai area. Energy Build. 2017, 140, 324-335. [CrossRef]

23. Consolino, F.; Banfi, E. The Simon E Schuster Guide to Climbing Plants; Simon and Schuster Inc.: New York, NY, USA, 1994; p. 255.

24. Gianoli, E. Using Ideas from Behavioural Ecology to Understand Plants. The Behavioural Ecology of Climbing Plants, AoB PLANTS 7: plv013. 2015. Available online: https://doi.org/10.1093/aobpla/plv013 (accessed on 18 April 2020).

25. Niklas, K.J. Climbing Plants: Attachment and the Ascent for Light. Curr. Biol. 2011, 21, 199-201. [CrossRef]

26. Turgeon, A.J. Turfgrass Management; Prentice Hall Inc.: Englewood Cliffs, NJ, USA, 1980; p. 418.

27. Beard, J.B. Turfgrass Science and Culture; Prentice Hall Inc.: Englewood Cliffs, NJ, USA, 1973; p. 658.

28. Croce, P.; De Luca, A.; Falcinelli, M.; Modestini, F.S.; Veronesi, F. Tappeti Erbosi, Cura, Gestione e Manutenzione Delle Aree Verdi Pubbliche e Private; Edagricole: Calderini, Bologna, Italy, 2006; p. 340.

29. Whittinghill, L.J.; Rowe, D.B.; Schutzki, R.; Cregg, B.M. Quantifying carbon sequestration of various green roof and ornamental landscape systems. Landsc. Urban Plan. 2014, 123, 41-48. [CrossRef]

30. Wood, A.; Bahrami, P.; Safarik, D. Green Walls in High-Rise Buildings: An output of the CTBUH Sustainability Working Group; Images publishing: Mulgrave, Victoria, Australia, 2014.

31. Chen, Q.; Li, B.; Liu, X. An experimental evaluation of the living wall system in hot and humid climate. Energy Build. 2013, 61, 298-307. [CrossRef]

32. Kontoleon, K.J.; Eumorfopoulou, E.A. The effect of the orientation and proportion of a plant-covered wall layer on the thermal performance of a building zone. Build. Environ. 2010, 45, 1287-1303. [CrossRef]

33. Manso, M.; Castro-Gomes, J.P. Thermal analysis of a new modular system for green walls. J. Build. Eng. 2016, 7, 53-62. [CrossRef]

34. Mårtensson, L.M.; Wuolo, A.; Fransson, A.M.; Emilsson, T. Plant performance in living wall systems in the Scandinavian climate. Ecol. Eng. 2014, 71, 610-614. [CrossRef]

35. Coma, J.; Perez, G.; de Gracia, A.; Bures, S.; Urrestarazu, M.; Cabeza, L.F. Vertical greenery systems for energy savings in buildings: A comparative study between green walls and green facades. Build. Environ. 2017, 111, 228-237. [CrossRef]

36. Cuce, E. Thermal regulation impact of green walls: An experimental and numerical investigation. Appl. Energy 2017, 194, 247-254. [CrossRef]

37. Cameron, R.W.F.; Taylor, J.E.; Emmett, M.R. What's 'cool' in the world of green façades? How plant choice influences the cooling properties of green walls. Build. Environ. 2014, 73, 198-207. [CrossRef]

38. Susorova, I.; Azimi, P.; Stephens, B. The effects of climbing vegetation on the local microclimate, thermal performance, and air infiltration of four building facade orientations. Build. Environ. 2014, 76, 113-124. [CrossRef]

39. Mazzali, U.; Peron, F.; Romagnoni, P.; Pulselli, R.M.; Bastianoni, S. Experimental investigation on the energy performance of Living Walls in a temperate climate. Build. Environ. 2013, 64, 57-66. [CrossRef]

40. Wong, N.H.; Tan, A.Y.K.; Chen, Y.; Sekar, K.; Tan, P.Y.; Chan, D.; Chiang, K.; Wong, N.C. Thermal evaluation of vertical greenery systems for building walls. Build. Environ. 2010, 45, 663-672. [CrossRef]

41. Cheng, C.Y.; Ken, K.; Cheung, S.; Chu, L.M. Thermal performance of a vegetated cladding system on facade walls. Build. Environ. 2010, 45, 1779-1787. [CrossRef]

42. Lacasta, A.M.; Penaranda, A.; Cantalapiedra, I.R.; Auguet, C.; Bures, S.; Urrestarazu, M. Acoustic evaluation of modular greenery noise barriers. Urban For. Urban Green. 2016, 20, 172-179. [CrossRef]

43. Perini, K.; Ottelé, M.; Fraaij, A.L.A.; Haas, E.M.; Raiteri, R. Vertical greening systems and the effect on air flow and temperature on the building envelope. Build. Environ. 2011, 46, 2287-2294. [CrossRef]

44. Eumorfopoulou, E.A.; Kontoleon, K.J. Experimental approach to the contribution of plant-covered walls to the thermal behaviour of building envelopes. Build. Environ. 2009, 44, 1024-1038. [CrossRef]

45. Scarpa, M.; Mazzali, U.; Peron, F. Modeling the energy performance of living walls: Validation against field measurements in temperate climate. Energy Build. 2014, 79, 155-163. [CrossRef]

46. Olivieri, F.; Olivieri, L.; Neila, J. Experimental study of the thermal-energy performance of an insulated vegetal façade under summer conditions in a continental Mediterranean climate. Build. Environ. 2014, 77, 61-76. [CrossRef]

47. Haggag, M.; Hassan, A.; Elmasry, S. Experimental study on reduced heat gain through green facades in a high heat load climate. Energy Build. 2014, 82, 668-674. [CrossRef] 
48. Razzaghmanesh, M. Thermal performance investigation of a living wall in a dry climate of Australia. Build. Environ. 2017, 112, 45-62. [CrossRef]

49. Ottelé, M.; Perini, K.; Fraaij, A.L.A.; Haas, E.M.; Raiteri, R. Comparative life cycle analysis for green facades and living wall systems. Energy Build. 2011, 43, 3419-3429. [CrossRef]

50. Mårtensson, L.M.; Fransson, A.M.; Emilsson, T. Exploring the use of edible and evergreen perennials in living wall systems in the Scandinavian climate. Urban For. Urban Green. 2016, 15, 84-88. [CrossRef]

51. Djedjig, R.; Ouldboukhitine, S.; Belarbi, R.; Bozonnet, E. Development and validation of a coupled heat and mass transfer model for green roofs. Int. Commun. Heat Mass Transf. 2012, 39, 752-761. [CrossRef]

52. Dahanayake, K.W.D.K.C.; Chow, C.L. Studying the potential of energy saving through vertical greenery systems: Using EnergyPlus simulation program. Energy Build. 2017, 138, 47-59. [CrossRef]

53. Malys, L.; Musya, M.; Inard, C. A hydrothermal model to assess the impact of green walls on urban microclimate and building energy consumption. Build. Environ. 2010, 73, 187-197. [CrossRef]

54. Djedjig, R.; Bozonnet, E.; Belarbi, R. Modeling green wall interactions with street canyons for building energy simulation in urban context. Urban Clim. 2016, 16, 75-85. [CrossRef]

55. Olivieri, F.; Redondas, D.; Olivieri, L.; Neila, J. Experimental characterization and implementation of an integrated autoregressive model to predict the thermal performance of vegetal facades. Energy Build. 2014, 72, 309-321. [CrossRef]

56. Pulselli, R.M.; Pulselli, F.M.; Mazzali, U.; Peron, F.; Bastianoni, S. Emergy based evaluation of environmental performances of LivingWall and Grass Wall systems. Energy Build. 2014, 73, 200-211. [CrossRef]

57. Vox, G.; Blanco, I.; Schettini, E. Green façades to control wall surface temperature in buildings. Build. Environ. 2018, 129, 154-166. [CrossRef]

58. Victorero, F.; Vera, S.; Bustamante, W.; Tori, F.; Bonilla, C.; Gironás, J.; Rojas, V. Experimental study of the thermal performance of living walls under semiarid climatic conditions. Energy Procedia 2015, 78, 3416-3421. [CrossRef]

59. Feitosa, R.C.; Wilkinson, S.J. Attenuating heat stress through green roof and green wall retrofit. Build. Environ. 2018, 140, 11-22. [CrossRef]

60. Herath, H.M.P.I.K.; Halwatura, R.U.; Jayasinghe, G.Y. Modeling a Tropical Urban Context with Green Walls and Green Roofs as an Urban Heat Island Adaptation Strategy. Procedia Eng. 2018, 212, 691-698. [CrossRef]

61. Hoelscher, M.T.; Nehls, T.; Jänicke, B.; Wessolek, G. Quantifying cooling effects of facade greening: Shading, transpiration and insulation. Energy Build. 2016, 114, 283-290. [CrossRef]

62. De Jesus, M.P.; Lourenço, J.M.; Arce, R.M.; Macias, M. Green façades and in situ measurements of outdoor building thermal behavior. Build. Environ. 2017, 119, 11-19. [CrossRef]

63. Marchi, M.; Pulselli, R.M.; Marchettini, N.; Pulselli, F.M.; Bastianoni, S. Carbon dioxide sequestration model of a vertical greenery system. Ecol. Model. 2015, 306, 46-56. [CrossRef]

64. Othman, R.; Kasim, S.Z.A. Assessment of Plant Materials Carbon Sequestration Rate for Horizontal and Vertical Landscape Design. Int. J. Environ. Sci. Dev. 2016, 7, 410-414. [CrossRef]

65. Paull, N.J.; Irga, P.J.; Torpy, F.R. Active green wall plant health tolerance to diesel smoke exposure. Environ. Pollut. 2018, 240, 448-456. [CrossRef]

66. Prodanovic, V.; Hatt, B.; McCarthy, D.; Zhang, K.; Deletic, A. Green walls for greywater reuse: Understanding the role of media on pollutant removal. Ecol. Eng. 2017, 102, 625-635. [CrossRef]

67. Prodanovic, V.; Zhang, K.; Hatt, B.; McCarthy, D.; Deletic, A. Optimisation of lightweight green wall media for greywater treatment and reuse. Build. Environ. 2018, 131, 99-107. [CrossRef]

68. Masi, F.; Bresciani, R.; Rizzo, A.; Edathoot, A.; Patwardhan, N.; Panse, D.; Langergraber, G. Green walls for greywater treatment and recycling in dense urban areas: A case-study in Pune. J. Water Sanit. Hyg. Dev. 2016, 6, 342-347. [CrossRef]

69. Brenneisen, S. Space for urban wildlife: Designing green roofs as habitats in Switzerland. Urban Habitats 2006, 4, 27-36.

70. Oberndorfer, E.; Lundholm, J.; Bass, B.; Coffman, R.R.; Doshi, H.; Dunnett, N.; Gaffin, S.; Köhler, M.; Liu, K.K.Y.; Rowe, B. Green roofs as urban ecosystems: Ecological structures, functions and services. BioScience 2007, 57, 823-833. [CrossRef]

71. Francis, R.A.; Lorimer, J. Urban reconciliation ecology: The potential of living roofs and walls. J. Environ. Manag. 2011, 92, 1429-1437. [CrossRef] [PubMed] 
72. Chiquet, C.; Dover, J.W.; Mitchell, P. Birds and the urban environment: The value of green walls. Urban Ecosyst. 2013, 16, 453-462. [CrossRef]

73. Lundholm, J.T. Green Roofs and Facades: A Habitat Template Approach. Urban Habitats 2006, 4, 87-101.

74. Collins, R.; Schaafsm, M.; Hudson, M.D. The value of green walls to urban biodiversity. Land Use Policy 2017, 64, 114-123. [CrossRef]

75. Gao, X.; Asami, Y. Effect of urban landscape on land price in two Japanese cities. Landsc. Urban Plan. 2007, 81, 155-166. [CrossRef]

76. Des Rosiers, F.; Thériault, M.; Kestens, Y.; Villeneuve, P. Landscaping and house values: An empirical investigation. J. Real Estate Res. 2002, 23, 139-161.

77. Coma, J.; Solé, C.; Castell, A.; Cabeza, L.F. New green facades as passive systems for energy savings on buildings. Energy Procedia 2014, 57, 1851-1859. [CrossRef]

78. Djedjig, R.; Belarbi, R.; Bozonnet, E. Experimental study of green walls impacts on buildings in summer and winter under an oceanic climate. Energy Build. 2017, 150, 403-411. [CrossRef]

79. Wong, I.; Baldwin, A.N. Investigating the potential of applying vertical green walls to high-rise residential buildings for energy-saving in sub-tropical region. Build. Environ. 2016, 97, 34-39. [CrossRef]

80. Feng, H.; Hewage, K. Energy saving performance of green vegetation on LEED certified buildings. Energy Build. 2014, 75, 281-289. [CrossRef]

81. Perini, K.; Bazzocchi, F.; Croci, L.; Magliocco, A.; Cattaneo, E. The use of vertical greening systems to reduce the energy demand for air conditioning. Field monitoring in Mediterranean climate. Energy Build. 2017, 143, 35-42. [CrossRef]

82. Wong, N.H.; Tan, A.Y.K.; Tan, P.Y.; Wong, N.C. Energy simulation of vertical greenery systems. Energy Build. 2009, 41, 1401-1408. [CrossRef]

83. Tudiwer, D.; Korjenic, A. The effect of living wall systems on the thermal resistance of the façade. Energy Build. 2017, 135, 10-19. [CrossRef]

84. Van Renterghem, T.; Hornikx, M.; Forssen, J.; Botteldooren, D. The potential of building envelope greening to achieve quietness. Build. Environ. 2013, 61, 34-44. [CrossRef]

85. Horoshenkov, K.V.; Khan, A.; Benkreira, H. Acoustic properties of low growing plants. J. Acoust. Soc. Am. 2013, 133, 2554-2565. [CrossRef] [PubMed]

86. Hong-Seok, Y.; Kang, J.; Chris, C. Random-Incidence Absorption and Scattering Coefficients of Vegetation. Acta Acust. United Acust. 2013, 99, 379-388.

87. Jang, H.S.; Kim, H.J.; Jeon, J.Y. Scale-model method for measuring noise reduction in residential buildings by vegetation. Build. Environ. 2015, 86, 81-88. [CrossRef]

88. Wong, N.H.; Tan, A.Y.K.; Tan, P.Y.; Chiang, K.; Wong, N.C. Acoustics evaluation of vertical greenery systems for building walls. Build. Environ. 2010, 45, 411-420. [CrossRef]

89. Azkorra, Z.; Pérez, G.; Coma, J.; Cabeza, L.F.; Bures, S.; Álvaro, J.E.; Erkoreka, A.; Urrestarazu, M. Evaluation of green walls as a passive acoustic insulation system for buildings. Appl. Acoust. 2015, 89, 46-56. [CrossRef]

90. Fernández-Bregón, N.; Urrestarazu, M.; Valera, D.L. Effects of a vertical greenery system on selected thermal and sound mitigation parameters for indoor building walls. J. Food Agric. Environ. 2012, 10, 1025-1027.

91. Pérez, G.; Coma, J.; Cabeza, L.F. Nature Based Strategies for Urban and Building Sustainability; Chapter 3.7-Vertical Greening Systems for Acoustic Insulation and Noise Reduction; Butterworth-Heinemann: Oxford, UK, 2018; pp. 157-165.

92. Giordano, R.; Montacchini, E.; Perone, A. Living Wall Systems: A technical standard proposal. Energy Procedia 2017, 111, 298-307. [CrossRef]

93. Tedesco, S.; Giordano, R.; Montacchini, E. How to measure the green façade sustainability? A proposal of a technical standard. Energy Procedia 2016, 96, 560-567. [CrossRef]

94. Feng, H.; Hewage, K. Lifecycle assessment of living walls: Air purification and energy performance. J. Clean. Prod. 2014, 69, 91-99. [CrossRef]

95. Manso, M.; Castro-Gomes, J.; Paulo, B.; Bentes, I.; Teixeira, C.A. Life cycle analysis of a new modular greening system. Sci. Total Environ. 2018, 627, 1146-1153. [CrossRef] [PubMed]

96. Perini, K.; Rosasco, P. Cost benefit analysis for green façades and living wall systems. Build. Environ. 2013, 70, 110-121. [CrossRef]

97. Perini, K.; Rosasco, P. Evaluating the economic sustainability of a vertical greening system: A Cost-Benefit, Analysis of a pilot project in mediterranean area. Build. Environ. 2018, 142, 524-533. 
98. Oquendo-Di Cosola, V.; Olivieri, F.; Ruiz-García, L.; Bacenetti, J. An environmental Life Cycle Assessment of Living Wall Systems. J. Environ. Manag. 2020, 254, 109743. [CrossRef]

99. Perez Urrestarazu, L.; Egea, G.; Franco-Salas, A.; Fernandez-Canero, R. Irrigation Systems Evaluation for Living Walls. J. Irrig. Drain. Eng. 2014, 140, 04013024. [CrossRef]

100. Perini, K.; Ottelé, M.; Haas, E.M.; Raiteri, R. Greening the building envelope, façade greening and living wall systems. Open J. Ecol. 2011, 1, 1. [CrossRef]

101. Sheweka, S.; Magdy, N. The Living walls as an Approach for a Healthy Urban Environment. Energy Procedia 2011, 6, 592-599. [CrossRef]

(C) 2020 by the authors. Licensee MDPI, Basel, Switzerland. This article is an open access article distributed under the terms and conditions of the Creative Commons Attribution (CC BY) license (http://creativecommons.org/licenses/by/4.0/). 